\title{
Streambank erosion in two watersheds of the Central Claypan Region of Missouri, United States
}

\author{
C.D. Willett, R.N. Lerch, R.C. Schultz, S.A. Berges, R.D. Peacher, and T.M. Isenhart
}

\begin{abstract}
This study was undertaken to assess the importance of streambank erosion to the total in-stream sediment of two agricultural watersheds within the Central Claypan Areas. The objective of this research was to determine the effect of stream order, adjacent land use, and season on streambank erosion rates. Thirty-four study sites were established in 2007 and 2008 within Crooked and Otter Creek watersheds, two claypan watersheds located in northeastern Missouri. At each site, field assessments of severely to very severely eroding bank length were determined along 300 to $400 \mathrm{~m}$ (984 to 1,312 ft) stream reaches. A factorial experimental design was implemented with four land uses (crop, forest, pasture, and riparian forest), three seasons, and three stream orders (1st, 2nd, and 3rd). Each treatment was replicated three times for each stream order, except for the cropped 3rd order treatment as only one suitable treatment site could be found. Streambank erosion was measured using erosion pins, which were installed in randomly assigned plots that included at least $20 \%$ of the eroded bank length within each site. The effect of different seasons was assessed by measuring the length of the exposed pins three times per year (March, July, and November). The bulk density and carbon and nitrogen content of bank material were also determined. Sediment loss rates showed that season and the three-way interaction between season, land use, and stream order were highly significant. Erosion rates were consistently higher in the winter months than spring/ summer and fall seasons; however, the significant three-way interaction precluded a simple interpretation of the seasonal effect. Soil nutrient concentration data showed that forest sites had significantly lower $\mathrm{C}$ and $\mathrm{N}$ concentrations than other land uses. At the watershed scale, bank sediment accounted for $79 \%$ to $96 \%$ of the total in-stream sediment and $21 \%$ to $24 \%$ of the total $\mathrm{N}$ exported from the study area. These results indicate that streambanks are the dominant source of sediment and a significant source of $\mathrm{N}$ in these streams. Therefore, improved management of riparian areas to decrease streambank erosion would result in significant water quality improvement in streams of the Central Claypan Areas in northeastern Missouri.
\end{abstract}

Key words: carbon—land use-nitrogen—stream order—streambank erosion-watershed scale transport

\begin{abstract}
Sedimentation is a significant environmental problem in agricultural watersheds (Wilson and Kuhnle 2006), with streambanks a major contributor to in-stream sediment (Simon et al. 1996; Zaimes et al. 2006; Fox et al. 2007; Piercy and Wynn 2008). In the Forked Deer River system in western Tennessee, Simon et al. (1996) reported that streambank erosion accounted for up to $80 \%$ of the in-stream sediment. Recent work utilizing stable isotopes has shown that streambank erosion can account for the majority of suspended
\end{abstract}

source of sediment in the streams of claypan watersheds (Jamison et al. 1968). No previous studies have reported on streambank erosion and its contribution to the sediment and nutrient load in watersheds of the Central Claypan Areas (Major Land Resource Area [MLRA] 113) (USDA NRCS 2006). The Central Claypan Areas encompass 33,150 $\mathrm{km}^{2} \quad\left(12,790 \mathrm{mi}^{2}\right)$ across northeastern Missouri and southeastern Illinois (figure 1) and are characterized by nearly level to gently sloping, mesic, aquic soils with clay loess or clayey glacial till as parent material. The key hydrologic feature of soils within MLRA 113 is a subsurface claypan with smectitic mineralogy. The claypan promotes surface runoff when it is at or near saturation by limiting the available water-holding capacity to the thickness of the soil above this restrictive layer. Therefore, other soils with smectitic mineralogy and the presence of argillic horizons or fragipans that also serve as restrictive layers will have similar hydrology to that of claypan soils.

As researchers and management specialists look to understand the causes and effects of water quality issues associated with sedimentation, the need to fully understand the sources of in-stream sediment and nutrients is critical to improving water quality at the watershed scale. This can only be accomplished by quantifying the relative contribution of both streambanks and overland erosion to the total in-stream sediment within a watershed. Furthermore, understanding the factors that control streambank erosion could provide the basis for targeting the placement of best management practices (BMPs) within watersheds to better mitigate streambank erosion at the watershed scale. The objective of this study was to investigate the effects of adjacent land use, season, and stream order on streambank erosion rates

Cammy D. Willett is a graduate research assistant in the Department of Soils, Environmental, and Atmospheric Sciences, University of Missouri, Columbia, Missouri. R. N. Lerch is a soil scientist in the USDA Agricultural Research Service, Cropping Systems and Water Quality Research Unit, Columbia, Missouri. Sara A. Berges is a former graduate research assistant, Rachel D. Peacher is a former graduate research assistant, Richard D. Schultz is a professor of forest ecology and hydrology, and Thomas $M$. Isenhart is a professor of Stream Ecology in the Department of Natural Resource, Ecology, and Management at lowa State University, Ames, lowa. 
and the associated loss of $\mathrm{C}$ and $\mathrm{N}$ in two watersheds of the Central Claypan Areas of northeastern Missouri. These results were then applied to the watershed scale to quantify the total contribution of streambank material to in-stream sediment and $\mathrm{N}$ transport in order to provide perspective on the overall importance of streambank erosion in claypan watersheds.

\section{Materials and Methods}

Site Description. Erosion pins were used to measure streambank erosion and deposition rates at 34 study sites established in Crooked and Otter Creek watersheds, located in northeastern Missouri within the Salt River Basin (figure 2). The Crooked Creek watershed is $288 \mathrm{~km}^{2}\left(110 \mathrm{mi}^{2}\right)$, with $56.0 \%$ of the area used for cropland, followed by pasture (26.5\%) and forest (14.5\%). The Otter Creek watershed encompasses a $272 \mathrm{~km}^{2}\left(105 \mathrm{mi}^{2}\right)$ area, with $64.6 \%$ in cropland, $20.3 \%$ in pasture, and $12.6 \%$ in forest (Lerch et al. 2008). The Crooked and Otter Creek watersheds are similar in size, soils, topography, and land use (Lerch et al. 2008) and were selected because they are representative of the intensively row-cropped claypan watersheds of MLRA 113 (figure 2) (Lerch and Blanchard 2003; Lerch et al. 2008).

Experimental Design. A factorial experimental design was implemented to evaluate the effects of land use, stream order, and season on streambank erosion of 1 st, 2 nd, and $3 \mathrm{rd}+$ order streams. The $3 \mathrm{rd}+$ category included a combination of $3 \mathrm{rd}$ and 4 th order streams as the extent of 3rd order stream reaches was very limited within these watersheds. Land use treatments included crop, forest, pasture, and riparian forest. Forest sites had minimum tree stands of $30 \mathrm{~m}(98 \mathrm{ft}$ ) wide on each side of the bank, while riparian

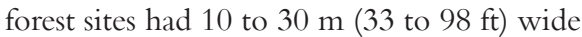
tree stands. Each treatment was replicated three times with some exceptions for some treatments across seasons. Exceptions were a result of not having the site established at the time measurements began or, in a few cases, because of restricted landowner access during measurement periods. Additionally, only one 3rd order crop site was established since two other suitable treatment sites could not be located. These missing values resulted in an unbalanced experiment (see Data Analysis). Erosion pin data were collected three times annually. The three seasons were defined as follows: Season 1-December through

\section{Figure 1}

Major Land Resource Area 113, Central Claypan Areas of Missouri and Illinois, United States.

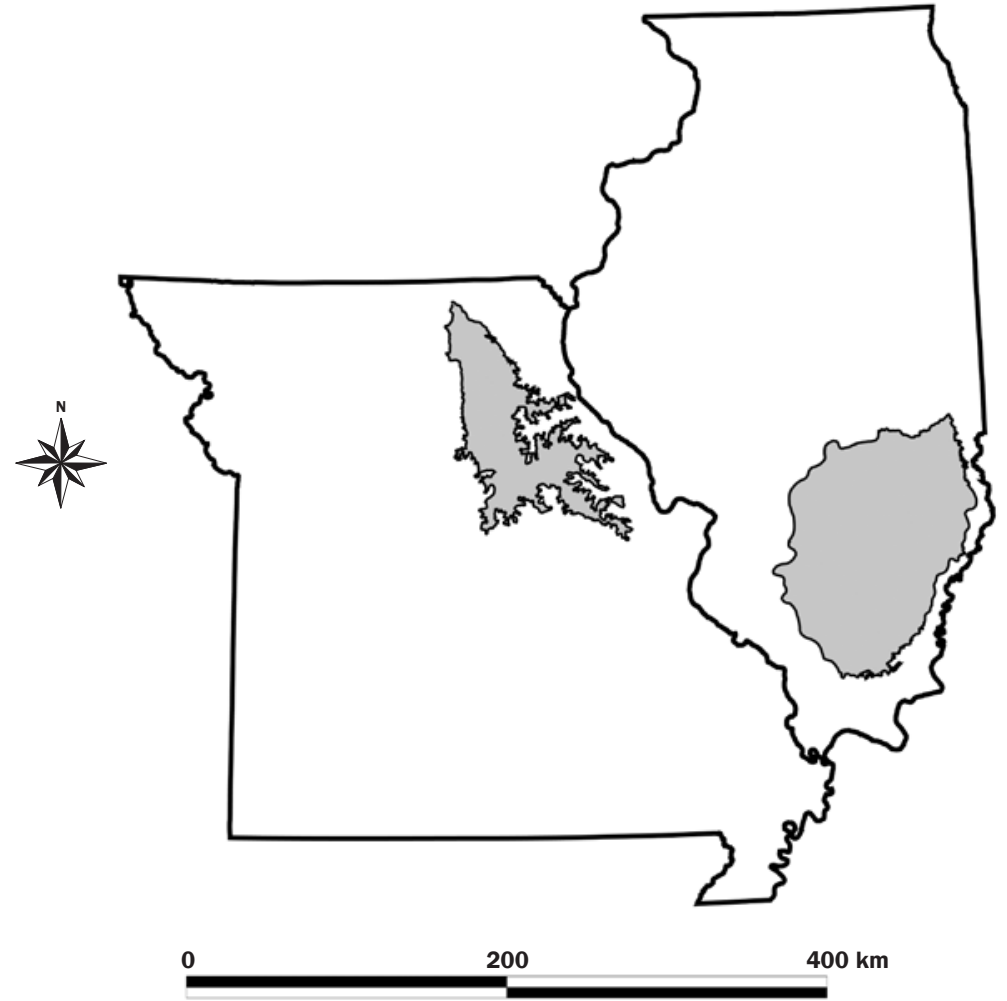

\section{Figure 2}

Crooked and Otter Creek streambank erosion site locations in northeastern Missouri, United States.

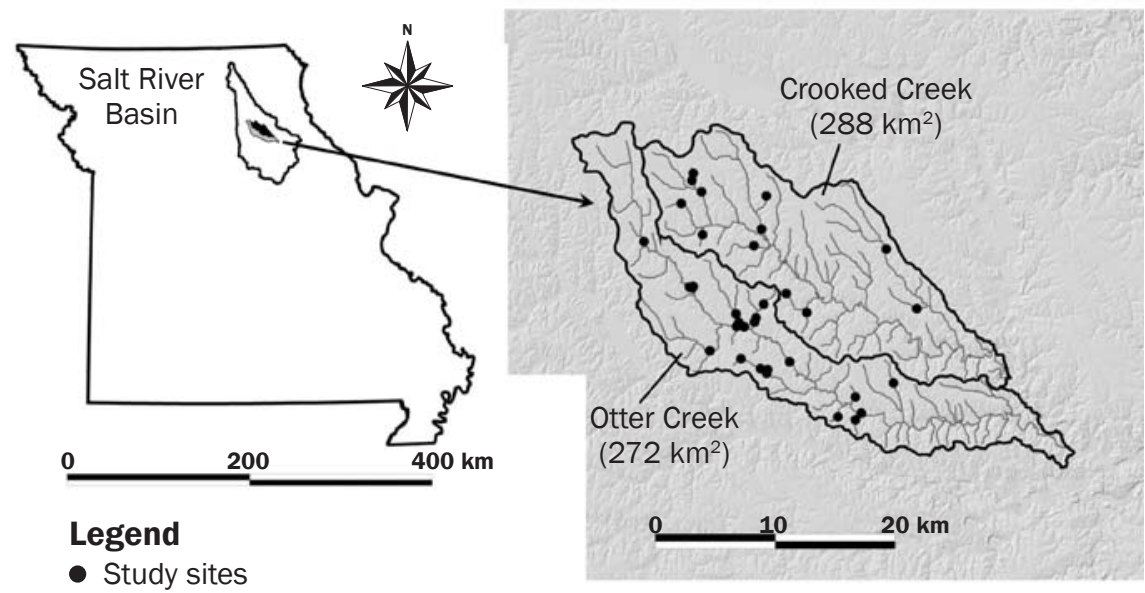

March; Season 2-April through July; and Season 3-August through November. Six sets of seasonal measurements, two for each season, were obtained in 2008 and 2009.

Site Setup. Site selection was based on the existence of a given land use treatment on both sides of the stream for approximately
$400 \mathrm{~m}(1,312 \mathrm{ft})$. Actual site lengths ranged from 300 to $425 \mathrm{~m}$ (984 to $1,394 \mathrm{ft}$ ), giving total streambank lengths of 600 to $850 \mathrm{~m}$ (1,969 to 2,789 ft) (table 1). Stream order was determined using the National Hydrography Dataset (Dewald and Roth 1998) and, in some cases, modified after ground truthing. 


\begin{tabular}{|c|c|c|c|c|c|}
\hline $\begin{array}{l}\text { Stream order, } \\
\text { land use, } \\
\text { replication } \\
\text { number }\end{array}$ & $\begin{array}{l}\text { Total } \\
\text { bank } \\
\text { length* }(m)\end{array}$ & $\begin{array}{l}\text { Eroding } \\
\text { length } \\
\text { (m) }\end{array}$ & $\begin{array}{l}\text { Bulk } \\
\text { density } \\
\left(\mathrm{Mg} \mathrm{m}^{-3}\right)\end{array}$ & $\begin{array}{l}\text { Carbon } \\
\left(\mathrm{g} \mathrm{kg}^{-1}\right)\end{array}$ & $\begin{array}{l}\text { Nitrogen } \\
\left(\mathrm{g} \mathrm{kg}^{-1}\right)\end{array}$ \\
\hline 1st crop 1 & 800 & 330 & 1.36 & 13.2 & 1.25 \\
\hline 1st crop 2 & 800 & 188 & 1.37 & 15.3 & 1.30 \\
\hline 1st crop 3 & 800 & 365 & 1.38 & 14.8 & 1.44 \\
\hline 1st forest 1 & 680 & 318 & 1.40 & 12.2 & 1.17 \\
\hline 1st forest 2 & 600 & 223 & 1.52 & 8.18 & 0.63 \\
\hline 1st forest 3 & 800 & 488 & 1.49 & 8.92 & 0.63 \\
\hline 1st pasture 1 & 800 & 567 & 1.40 & 11.9 & 0.94 \\
\hline 1st pasture 2 & 800 & 186 & 1.36 & 15.1 & 1.30 \\
\hline 1st pasture 3 & 800 & 580 & 1.49 & 12.0 & 0.93 \\
\hline 1st riparian 1 & 800 & 573 & 1.43 & 13.8 & 1.18 \\
\hline 1st riparian 2 & 800 & 689 & 1.30 & 15.0 & 1.30 \\
\hline 1st riparian 3 & 800 & 665 & 1.48 & 10.1 & 0.76 \\
\hline 2nd crop 1 & 800 & 800 & 1.26 & 19.2 & 1.59 \\
\hline 2nd crop 2 & 800 & 459 & 1.40 & 12.6 & 1.11 \\
\hline 2nd crop 3 & 800 & 549 & 1.30 & 17.8 & 1.48 \\
\hline 2nd forest 1 & 800 & 467 & 1.63 & 5.93 & 0.31 \\
\hline 2 nd forest 2 & 800 & 321 & 1.47 & 10.5 & 0.99 \\
\hline 2 nd forest 3 & 880 & 252 & 1.48 & 9.8 & 0.78 \\
\hline 2nd pasture 1 & 800 & 780 & 1.45 & 12.1 & 0.98 \\
\hline 2nd pasture 2 & 850 & 145 & 1.37 & 13.6 & 1.34 \\
\hline 2nd pasture 3 & 800 & 294 & 1.34 & 18.9 & 1.76 \\
\hline 2nd riparian 1 & 800 & 186 & 1.49 & 10.1 & 0.80 \\
\hline 2nd riparian 2 & 800 & 178 & 1.48 & 14.3 & 1.34 \\
\hline 2nd riparian 3 & 800 & 364 & 1.36 & 13.1 & 1.11 \\
\hline 3rd crop & 800 & 423 & 1.48 & 11.2 & 0.93 \\
\hline 3rd forest 1 & 800 & 134 & 1.48 & 8.73 & 0.80 \\
\hline 3rd forest 2 & 800 & 240 & 1.38 & 14.9 & 1.26 \\
\hline 3rd forest 3 & 700 & 340 & 1.41 & 11.8 & 0.99 \\
\hline 3rd pasture 1 & 800 & 703 & 1.42 & 11.6 & 0.99 \\
\hline 3rd pasture 2 & 800 & 690 & 1.42 & 12.8 & 1.06 \\
\hline 3rd pasture 3 & 800 & 463 & 1.49 & 11.3 & 0.95 \\
\hline 3rd riparian 1 & 800 & 268 & 1.52 & 9.02 & 0.76 \\
\hline 3rd riparian 2 & 800 & 562 & 1.35 & 13.6 & 1.22 \\
\hline 3rd riparian 3 & 800 & 562 & 1.36 & 16.9 & 1.45 \\
\hline
\end{tabular}

* Total bank length represents the total length of streambank for each site (i.e., twice the stream reach length).

To determine the total eroded bank length, surveys were conducted using handheld Global Positioning System units (Juno ST, Trimble Navigation Ltd., Sunnyvale, California or Dell X51 with GlobalSat BC337 Compact Flash GPS Receiver, Dell Computers Inc., Round Rock, Texas, 2 to 5 $\mathrm{m}$ [6.6 to $16.5 \mathrm{ft}]$ accuracy) and Trac-Mate software (Farm Works Software, Version 12.16, CTN Data Services Inc., Hamilton, Indiana). Distances between eroding and noneroding sections along each bank were recorded. Eroding banks were identified based on the USDA NRCS (1998) criteria for severely and very severely eroded banks, which were developed for calculating erosion and sediment delivery based on visual inspection of streambanks. This approach has been used in previous streambank erosion studies (Zaimes et al. 2006; Berges 2009; Willett et al. 2009; and Willett 2010). Banks identified as severely to very severely eroding possessed one or more of the following characteristics: two-thirds of the bank face devoid of veg- etative growth or roots; less than one-third of bank face protected by roots; overhanging vegetation with eroded undercut face; near vertical slope; and apparent bank failures, such as slumps and slides. Summary characteristics for each site are listed in table 1. The site length listed in table 1 represents the total length of streambank for each site (i.e., twice the stream reach length); the eroded lengths were computed based on the GPS survey data.

After surveys were conducted, each 300 to $425 \mathrm{~m}$ (984 to $1,394 \mathrm{ft})$ reach was subdivided into four equal length subreaches. The total eroded length for each subreach was calculated using the GPS data from the bank surveys, and pin plot placement was randomly assigned, with pins installed on at least $20 \%$ of the eroded length for that subreach. This resulted in three to eight pin plots per site. Erosion pins made of rolled steel (76.2 $\mathrm{cm}$ long and $6.2 \mathrm{~mm}$ diameter $[2.5 \mathrm{ft}$ long and 0.24 in diameter]) were then installed perpendicular to the bank face at each site to measure streambank erosion. For banks of $1 \mathrm{~m}(3.3 \mathrm{ft})$ or less, one row of pins was placed at one-half of the bank height. For banks greater than $1 \mathrm{~m}(3.3 \mathrm{ft})$ but less than $2 \mathrm{~m}(6.6 \mathrm{ft})$, two rows were installed at onethird and two-thirds bank height. Three rows were installed for banks over $2 \mathrm{~m}$ (6.6 ft), with rows at one-fourth, one-half, and threefourths bank height. Laterally, pins were spaced $2 \mathrm{~m}(6.6 \mathrm{ft})$ apart. An example of pin placement on a 3rd order stream is shown in figure 3. Pins were inserted horizontally into eroded banks with $10.2 \mathrm{~cm}$ (4 in) of the pin exposed. In total, there were 3,150 individual erosion pins installed. After pin installation, the bank area of each pin plot was measured. Methods reported here were similar to previously reported studies (Zaimes et al. 2004, 2006, and 2008; Berges 2009; Willett et al. 2009; and Willett 2010).

Data Collection. Pin plots were installed beginning in late June through August of 2007, with exceptions as previously noted. Each pin was measured for deposition or erosion of bank material three times annually by measuring the length of the exposed pin. Pins that had been completely eroded were recorded as $65 \mathrm{~cm}$ (2.1 ft), which was considered reasonable based on the recommendations of past studies (Lawler 1993). Where deposition occurred, negative pin lengths were recorded. The inclusion of negative erosion data is seen as the best approach 
Figure 3

Pin arrangement on a zrd order stream. Banks are approximately $2.5 \mathrm{~m}$ high. Circles indicate the location of erosion pins.

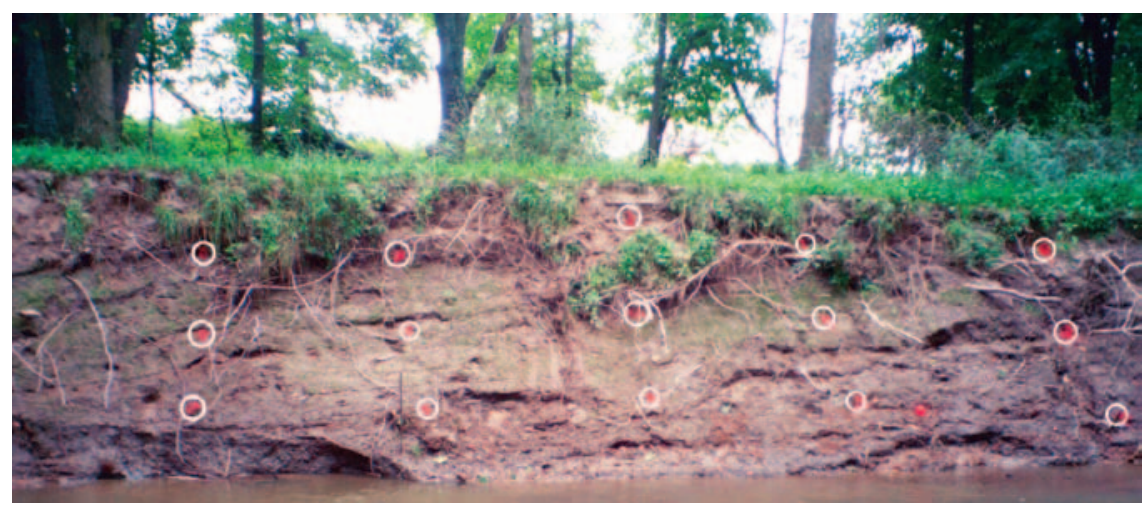

for calculating the actual amount of erosion because omitting negative readings or replacing negative readings with zeros artificially increases the calculated erosion rate (Couper et al. 2002). A length of $-10.2 \mathrm{~cm}$ ( -4 in) was used for pins that were completely buried. Pins that could not be relocated and were without evidence of either erosion or deposition were recorded as missing and replaced with a new pin.

Bulk density and nutrient samples were taken over the course of the summer and fall of 2008. Fifty percent, or a minimum of three, of the plots at each site were sampled. Bulk density cores and soil samples were collected for $\mathrm{C}$ and $\mathrm{N}$ analysis for each identified soil horizon. Soil profile descriptions were recorded for each horizon from which a corresponding bulk density and soil sample was collected (Willett 2010). Bulk density soil cores were collected using Uhland soil cores with a $346.86 \mathrm{~cm}^{3}\left(21.2 \mathrm{in}^{3}\right)$ volume. Soil cores were oven dried at $110^{\circ} \mathrm{C}\left(230^{\circ} \mathrm{F}\right)$ for a minimum of 72 hours, brought to room temperature in a desiccator, and weighed. Bulk densities were computed on a depthweighted basis for each pin plot and averaged over the number of plots sampled to obtain a depth-weighted average for each site. Soils collected for $\mathrm{C}$ and $\mathrm{N}$ analysis were air-dried, sieved to $2 \mathrm{~mm}$ (0.08 in), and then crushed using a mortar and pestle. Prior to the total C analysis, a representative subset of samples was tested for the presence of carbonates, using $\mathrm{HCl}$ effervescence as an indicator. None of the tested samples effervesced, and therefore, it was concluded that carbonates were not present in any of the samples. Crushed, airdried samples were then analyzed for $\mathrm{C}$ and $\mathrm{N}$ content using the LECO TruSpec NC
Carbon/Nitrogen Determinator (St. Joseph, Michigan). Combustion was at $950^{\circ} \mathrm{C}$ $\left(1,742^{\circ} \mathrm{F}\right)$. An infrared radiation cell was used to determine $\mathrm{C}$ content, and a thermal conductivity cell was used to determine the $\mathrm{N}$ content on a percentage basis. Moisture content of air-dried samples was determined for each sample by drying at $105^{\circ} \mathrm{C}$ to $110^{\circ} \mathrm{C}$ $\left(221^{\circ} \mathrm{F}\right.$ to $\left.230^{\circ} \mathrm{F}\right)$ for a minimum of 48 hours so that the $\mathrm{C}$ and $\mathrm{N}$ data could be corrected to a dry weight basis. In total, 416 soil samples were analyzed for bulk density and C and $\mathrm{N}$ content.

Sediment and Nutrient Loss Calculations. Following computation of the net pin length for a given seasonal data set, the mass of eroded or deposited sediment was computed based on the average net pin length (m) for an entire pin plot multiplied by the plot area $\left(\mathrm{m}^{2}\right)$ and average site bulk density $\left(\mathrm{kg} \mathrm{m}^{-3}\right)$. This mass $(\mathrm{kg})$ was then divided by the pin plot length $(\mathrm{m})$ to give a linear erosion or deposition rate $\left(\mathrm{kg} \mathrm{m}^{-1}\right.$ season $\left.^{-1}\right)$ for each pin plot. The average linear erosion rates of the pin plots were then multiplied by the total eroded length $(\mathrm{m})$ of each site (based on the initial GPS surveys described above), giving the total mass $(\mathrm{kg})$ of eroded or deposited sediment for the entire site. The linear erosion or deposition rate of each site (entire stream reach) was computed by dividing the total eroded or deposited mass by the total site length (table 1). To compute $\mathrm{C}$ and $\mathrm{N}$ loss rates, the concentration data $\left(\mathrm{g} \mathrm{kg}^{-1}\right)$ were multiplied by the linear erosion rate to obtain the nutrient loss rates $\left(\mathrm{g} \mathrm{m}^{-1}\right.$ season $\left.^{-1}\right)$ for each site.

Data Analysis. As discussed above, the experimental design was a three-way factorial with main factors of land use, stream order, and season. The analysis of variance (ANOVA) model for the sediment loss rates included all levels of interaction and was performed using SAS v9 statistical software (SAS Institute Inc., Cary, North Carolina). The MIXED PROC ANOVA was used with the REPEATED statement included to account for the differences in variability within and between sites resulting from repeated measurements at the same site. Allowance for dependence among the six observations (three seasons over two years) was accomplished by using an unstructured correlation model. After the ANOVA model was fit (Model 1), the residuals were examined to assess the assumption of normality. Analysis using all of the sediment loss data showed that the residuals, though not highly skewed, had a distribution that may not be normal. Consequently, a second analysis (Model 2) was performed using the transformation $\mathrm{Y}=\log (50+$ erosion rate $)$. A value of 50 was used to force all the transformed data to be greater than zero. Analysis of the residuals from this model showed two outliers (standardized residuals greater than 3 in absolute value). When the model was run with these outliers excluded, the resulting residuals were normally distributed. A conservative approach was taken such that main effects, interactions, and pair-wise comparisons were considered significant only if they were significant for both models (Models 1 and 2). Because the data were unbalanced, least squared means (LS means) were used as the basis for all statistical inferences (i.e., determinations of significance for the main effects, interactions, and pair-wise comparisons). However, arithmetic means were used to compare our results to those in the literature and for computing the study area scale estimates of bank erosion and associated nutrient transport (see Watershed Scale Estimates section); thus, arithmetic means were also reported in figures 3, 4, and 5 . In view of the large number of comparisons, a more stringent $\alpha=0.01$ was used to determine significance of the pair-wise LS mean comparisons rather than the more commonly used $\alpha=0.05$. For main effects and interactions, $\alpha=0.05$ was used to determine statistical significance.

The nutrient concentration data were analyzed using a MIXED PROC ANOVA procedure in SAS, and pair-wise comparisons were made using LS means because the missing 3rd order crop replicates resulted in 


\section{Figure 4}

Sediment erosion rates for each land use treatment (means averaged over season and stream order).

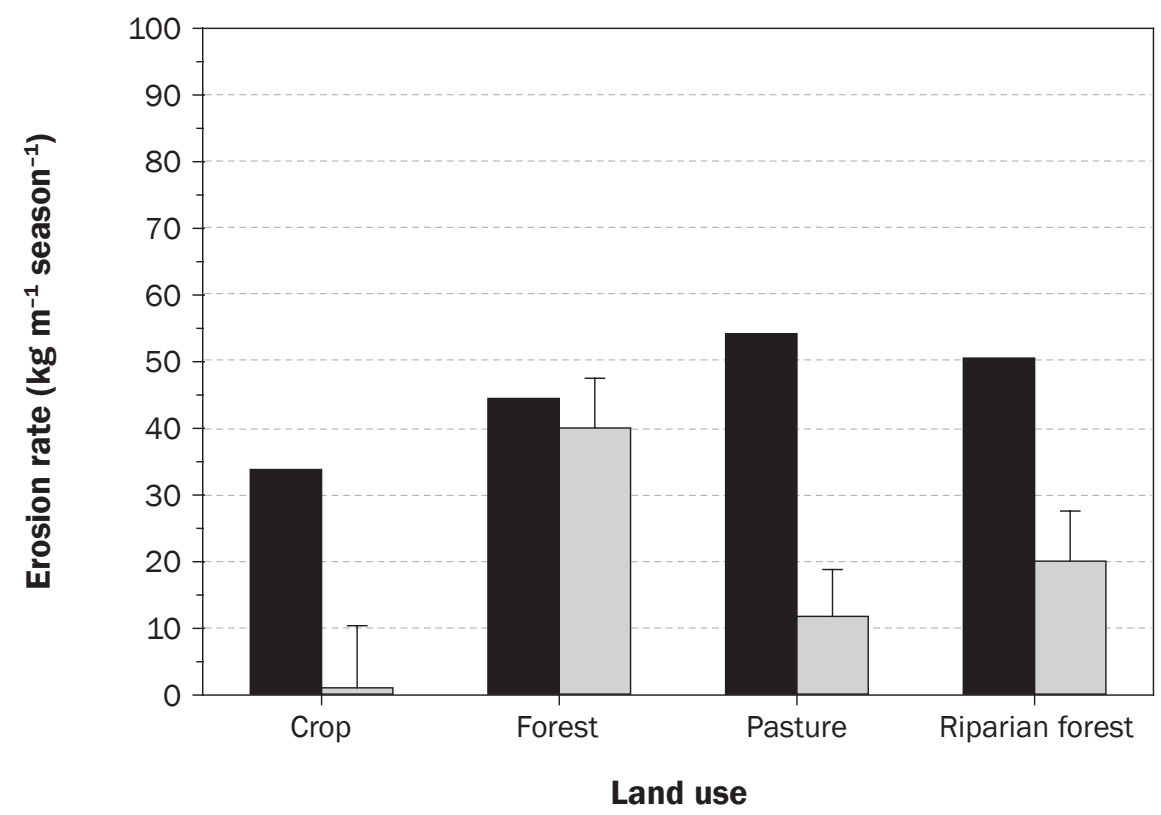

\section{Legend}

Arithmetic means $\square$ Least squared means with standard error

\section{Figure 5}

Sediment erosion rates for each stream order (means averaged over land use and season).

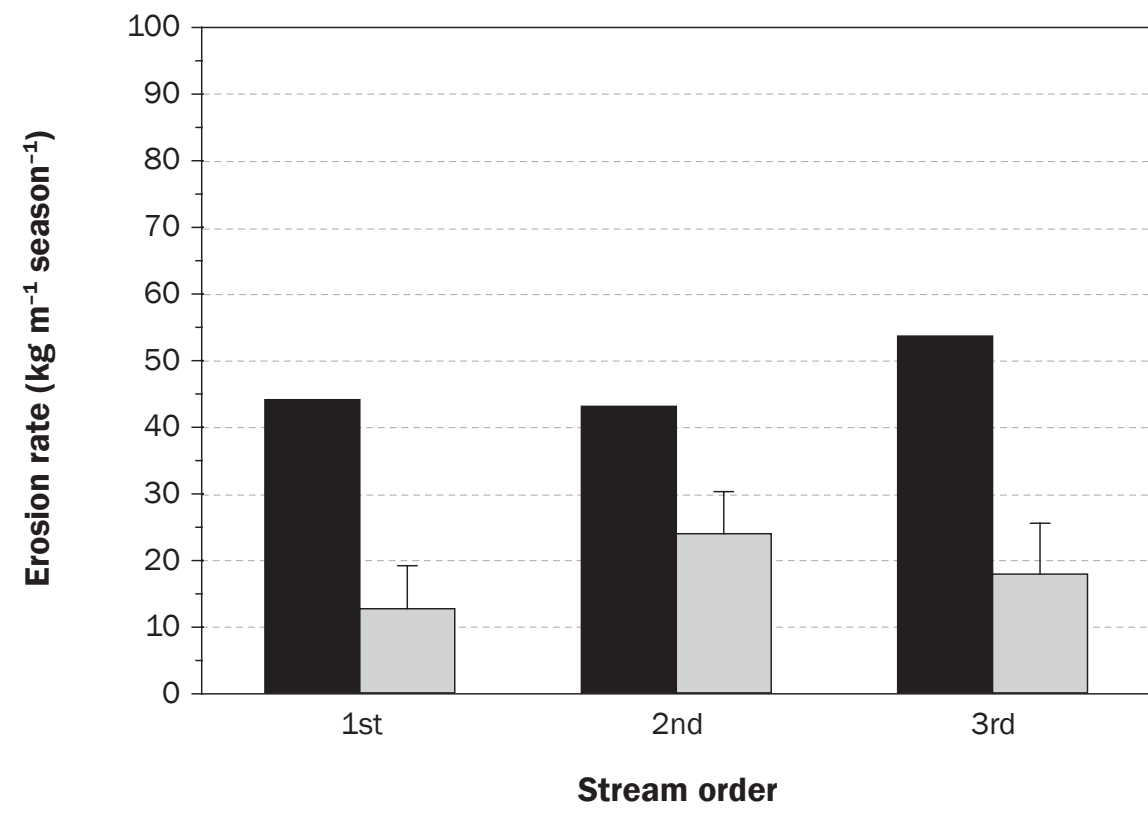

Legend

Simple means

Least squared means with standard error

an unbalanced experiment. The data contained no outliers or extreme values. The initial analysis was run including the two-way interaction term (land use by stream order), which was not significant for either the $\mathrm{C}$ or $\mathrm{N}$ data. Therefore, simple main effect models were run. The $\mathrm{C}$ and $\mathrm{N}$ concentration data are listed by site in table 1 . The same statistical analysis used for the sediment loss rates (discussed above) was used to analyze the $\mathrm{C}$ and $\mathrm{N}$ loss rates. The nutrient loss rate data also contained outliers because they are the product of the sediment loss rates and the nutrient concentrations. Thus, two models were run (as described above for the sediment loss data), one with all the data (Model 1) and the other with outliers omitted to meet the assumption of normality (Model 2). Only main effects, interactions $(\alpha=0.05)$, and pair-wise comparisons $(\alpha=0.01)$ that were significant in both models were considered statistically significant.

Watershed Scale Estimates. Overland erosion has historically been the primary focus of erosion control efforts in the Central Claypan Areas. Thus, a primary goal of this work was to determine the relative importance of streambank erosion to the total in-stream sediment and $\mathrm{N}$ transport at the watershed scale. All mass estimates for watershed scale in-stream sediment and $\mathrm{N}$ transport were calculated for the combined area of Crooked and Otter Creek (i.e., the entire study area of $560 \mathrm{~km}^{2}\left(216 \mathrm{mi}^{2}\right.$ ) (figure 2). The National Hydrography Data Set (Dewald and Roth 1998) was used to calculate the total length of streams in the watershed by stream order. Within the study area, there are a total of $1,365 \mathrm{~km}(848 \mathrm{mi})$ of streambank length (streambank length $=$ stream channel length $\times 2$ banks). Applying the annual sediment and nutrient erosion rates for each stream order and multiplying by the length of the corresponding stream order in the study area gave an estimate of the mass of streambank sediment or nutrients that were deposited in the streams of these watersheds. The arithmetic mean annual linear erosion rates for each stream order were used to compute the total mass of in-stream sediment and $\mathrm{N}$ derived from streambanks. Although the sediment and nutrient loss rates were not significantly different between stream orders, they were numerically different. Therefore, mean annual sediment and nutrient loss rates were based on stream order to provide the best mass estimates as opposed to applying a 


\section{Table 2}

Study area land use and overland erosion rates using USDA Natural Resources Conservation Service annual tolerable soil loss T-values (NAS 1986; USDA NRCS 2000a, 2000b).

\begin{tabular}{|c|c|c|c|c|}
\hline Land use & Area (ha) & $\begin{array}{l}\text { Fraction of } \\
\text { study area (\%) }\end{array}$ & $\begin{array}{l}\text { Erosion rate } \\
\left(\mathrm{Mg} \mathrm{ha}^{-1}\right)\end{array}$ & $\begin{array}{l}\text { Total mass } \\
\text { eroded (Mg) }\end{array}$ \\
\hline Impervious/urban & 865 & 1.5 & 0 & 0 \\
\hline \multicolumn{5}{|l|}{ Cropland (T-value) } \\
\hline $0.75 \mathrm{~T}$ & 13,782 & 24.6 & 5.7 & 78,600 \\
\hline $1 \mathrm{~T}$ & 11,918 & 21.3 & 7.6 & 90,600 \\
\hline $2 \mathrm{~T}$ & 5,397 & 9.6 & 15.2 & 82,000 \\
\hline $3 \mathrm{~T}$ & 2,024 & 3.6 & 22.8 & 46,100 \\
\hline $4 \mathrm{~T}$ & 1,124 & 2.0 & 30.4 & 34,200 \\
\hline $5 \mathrm{~T}$ & 2,024 & 3.6 & 38.0 & 76,900 \\
\hline Total & 36,268 & 64.7 & 5.7 to 38 & 408,000 \\
\hline \multicolumn{5}{|l|}{ Pasture (T-value) } \\
\hline $0.5 \mathrm{~T}$ & 10,893 & 19.4 & 3.8 & 41,400 \\
\hline $1 \mathrm{~T}$ & 754 & 1.3 & 7.6 & 5,730 \\
\hline $2 \mathrm{~T}$ & 172 & 0.3 & 15.2 & 2,620 \\
\hline $3 \mathrm{~T}$ & 151 & 0.3 & 22.8 & 3,440 \\
\hline Total & 11,970 & 21.4 & 3.8 to 22.8 & 53,200 \\
\hline Forest and wetland & 6,503 & 11.6 & 1.9 & 12,400 \\
\hline Open water & 441 & 0.8 & 0 & 0 \\
\hline Study area total & 56,047 & 100.0 & - & 474,000 \\
\hline
\end{tabular}

single grand mean for the entire study area. The range of the estimates was calculated using the 2008 and 2009 data.

To estimate overland erosion, the tolerable soil loss rate (T-value) was used. For the study area, the T-value is estimated to be $7.6 \mathrm{Mg}$ $\mathrm{ha}^{-1} \mathrm{y}^{-1}$ (3.4 tn $\left.\mathrm{ac}^{-1} \mathrm{yr}^{-1}\right)$ (Lerch et al. 2008; National Academy of Sciences 1986). While the T-value represents the maximum amount of erosion that can occur and still sustain high levels of crop productivity, much of the land in the study area exceeds this threshold. Data from the USDA Natural Resources Conservation Service was used to estimate erosion from cropland (USDA NRCS 2000a) and pasture (USDA NRCS 2000b) that exceeds the T-value. Table 2 contains the total and percentage area of each land use and the assumed erosion rate applied as a fraction of the T-value for each land use for the entire study area (i.e., both watersheds combined). Conservative estimates of rates less than the T-value were used for cropland and pasture land not exceeding the T-value and for noncropped and nonpasture land uses. Because estimates of the total area in pasture (assumed to be grazed by cattle) versus grasslands producing hay were not available, all grassland was assumed to be pasture, and erosion rates were applied accordingly (NRCS 2000b).

For streambank erosion, it is reasonable to assume that $100 \%$ of bank sediments are delivered to the stream. However, to estimate the percentage of overland sediment that reaches the stream, a sediment delivery ratio (SDR) must be applied.The SDR is the ratio of annual sediment yield to annual gross erosion (USDA SCS 1983), or more generally, the percentage of sediment that arrives at a point of reference in comparison to the gross erosion that occurred above that point (Roehl 1962; Duijsings 1986). Approaches specifically designed for estimating SDR in claypan watersheds were not reported in existing literature, nor has a given SDR equation gained prominence as the preferred method.Therefore, the approach used here was to apply multiple models to calculate a range of estimates for the SDR of these watersheds. Four SDR models were chosen, two based on relief and length (Maner 1958; Roehl 1962) and two based on watershed area (Roehl 1962; USDA SCS 1983). Model inputs were averaged across the two watersheds and included relief $(\mathrm{R})=67.1 \mathrm{~m}(220 \mathrm{ft})$ and length $(\mathrm{L})=$ $65,900 \mathrm{~m}(216,300 \mathrm{ft})$, giving $\mathrm{R} / \mathrm{L}=0.001$; and area $(\mathrm{A})=280 \mathrm{~km}^{2}\left(108 \mathrm{mi}^{2}\right)$.

The total loss of nitrogen on a yearly basis was estimated using stream discharge and total nitrogen concentration data for Crooked and Otter Creek, which have been monitored year-round since 2005 as part of the Conservation Effects Assessment Project (Lerch et al. 2008). Daily discharge data for Crooked Creek (station number 05503800) were obtained from the U. S. Geological Survey (2009). The daily discharge data for
Otter Creek were based on rating curves developed by the USDA Agricultural Research Service (Lerch et al. 2008). As part of the monitoring effort, water samples were collected from each stream for determination of total $\mathrm{N}$ concentrations. Grab samples were collected at least twice monthly under base flow conditions and during the winter months (December to March). Sigma 900 Max automated samplers (Hach Co., Loveland, Colorado) were used to collect flow-proportional samples under runoff conditions from April through November of both years when stage rose approximately $0.15 \mathrm{~m}(0.49 \mathrm{ft})$. Runoff samples were composited into $10 \mathrm{~L}$ (2.6 gal) bottles. In 2008 and 2009, a total of 74 samples per site were collected. Total $\mathrm{N}$ concentrations of unsampled days were determined by linear interpolation to provide daily estimates for the entire two-year period. Because the discharge data at Otter Creek were not collected from December to March, the missing data for Otter Creek were estimated based on Crooked Creek discharge. Linear regression was used to generate an equation to estimate Otter Creek discharge for days in which discharge data existed at both sites. The following relationship was then applied to estimate Otter Creek discharge:

Otter $=0.7912 \times$ Crooked $+73,008$,

where Otter $=$ daily Otter Creek discharge in $\mathrm{m}^{3}$, Crooked $=$ daily Crooked Creek discharge in $\mathrm{m}^{3}$, and $r^{2}=0.85$.

Total $\mathrm{N}$ was determined on thoroughly mixed, unfiltered $60 \mathrm{~mL}(2 \mathrm{oz})$ samples by autoclave digestion with potassium persulfate (Nydahl 1978). The persulfate digestion quantitatively converts all $\mathrm{N}$ forms to nitrate $\left(\mathrm{NO}_{3}^{-}\right)$, which was then determined colorimetrically by the cadmium reduction method (Greenberg et al. 1992). Nitrate analysis was performed by an Aquakem 200 discrete colorimetric analyzer (Environmental Science Technology, Fairfield, Ohio).

Total $\mathrm{N}$ loads were then determined on a daily basis for each watershed by multiplying the total $\mathrm{N}$ concentration by the discharge and summing the daily loads for the entire two year period for both sites. The monitored areas were $74 \%$ of the watershed for Crooked Creek and $84 \%$ of the watershed for Otter Creek. Total $\mathrm{N}$ loss rates for the unmonitored area were assumed to be equal to the loss rates of the monitored area. Thus, the estimated 
loads from the monitoring data were corrected to a whole watershed basis by dividing the computed total $\mathrm{N}$ loads for each site by the fraction of the watershed monitored. The total $\mathrm{N}$ loads for each watershed were then summed to acquire the total $\mathrm{N}$ loads for the study area for both 2008 and 2009.

\section{Results and Discussion}

Sediment Erosion Rates-Main Factors. The arithmetic mean erosion rates for the land use treatments, averaged across season and stream order, were $34 \mathrm{~kg} \mathrm{~m}^{-1}$ season $^{-1}$ (23 $\mathrm{lb} \mathrm{ft}{ }^{-1}$ season $^{-1}$ ) for crop, $44 \mathrm{~kg} \mathrm{~m}^{-1}$ season $^{-1}$ $\left(30 \mathrm{lb} \mathrm{ft}^{-1}\right.$ season $^{-1}$ ) for forest, $54 \mathrm{~kg} \mathrm{~m}^{-1}$ sea$\operatorname{son}^{-1}\left(36 \mathrm{lb} \mathrm{ft}^{-1}\right.$ season $\left.^{-1}\right)$ for pasture, and 51 $\mathrm{kg} \mathrm{m}^{-1}$ season $^{-1}\left(34 \mathrm{lb} \mathrm{ft}^{-1}\right.$ season $\left.^{-1}\right)$ for riparian forest (figure 4). Mean erosion rates for the stream orders, averaged across season and land use, were 44,43 , and $54 \mathrm{~kg} \mathrm{~m}^{-1}$ season $^{-1}$ $\left(30,29\right.$, and $36 \mathrm{lb} \mathrm{ft}^{-1}$ season $\left.^{-1}\right)$ for $1 \mathrm{st}, 2 \mathrm{nd}$, and 3 rd order streams, respectively (figure 5). Seasonal means, averaged across land use and stream order, were $96 \mathrm{~kg} \mathrm{~m}^{-1}$ season $^{-1}(65 \mathrm{lb}$ $\mathrm{ft}^{-1}$ season $^{-1}$ ) for Season 1, $36 \mathrm{~kg} \mathrm{~m}^{-1}$ season $^{-1}$ $\left(24 \mathrm{lb} \mathrm{ft}^{-1}\right.$ season $\left.^{-1}\right)$ for Season 2 , and $8.5 \mathrm{~kg}$ $\mathrm{m}^{-1}$ season $^{-1}\left(5.7 \mathrm{lb} \mathrm{ft}^{-1}\right.$ season $\left.^{-1}\right)$ for Season 3 (figure 6). Combining the seasonal rates, the annual erosion rate was $141 \mathrm{~kg} \mathrm{~m}^{-1} \mathrm{y}^{-1}$ (95 $\left.\mathrm{lb} \mathrm{ft}^{-1} \mathrm{yr}^{-1}\right)$. These erosion rates were similar to those found in other bank erosion studies (McGreal and Gardiner 1977; Gardiner 1983; DeWolfe et al. 2004; Zaimes et al. 2006). Zaimes et al. (2006) reported erosion rates of 5 to $304 \mathrm{~kg} \mathrm{~m}^{-1} \mathrm{y}^{-1}$ (3.4 to $204 \mathrm{lb} \mathrm{ft}^{-1} \mathrm{yr}^{-1}$ ) in Iowa streams with various riparian land uses. Likewise, DeWolfe et al. (2004) reported erosion rates of 10 to $447 \mathrm{~kg} \mathrm{~m}^{-1} \mathrm{y}^{-1}$ (6.7 to 300 $\left.\mathrm{lb} \mathrm{ft} \mathrm{fr}^{-1} \mathrm{yr}^{-1}\right)$ in Vermont watersheds ranging in size from 108 to $202 \mathrm{~km}^{2}$ (42 to $78 \mathrm{mi}^{2}$ ) with grass, pasture, and riparian forest land uses. Average erosion rates for this study, when expressed in $\mathrm{m} \mathrm{y}^{-1}$, were also within the range of reported values $(0.004$ to $0.387 \mathrm{~m}$ $\mathrm{y}^{-1}\left[0.001\right.$ to $\left.0.118 \mathrm{ft} \mathrm{yr}^{-1}\right]$ ) from erosion pin studies in watersheds of similar size (McGreal and Gardiner 1977; Gardiner 1983).

Sediment Erosion Rates-Statistical Analysis. The effect of season and the threeway interaction between season, land use, and stream order were found to be significant, but land use and stream order main effects were not significant (table 3 ). In addition, no two-way interactions were found to be significant. The significant differences observed can be explained in part by the overwhelming importance of season on streambank erosion

\section{Figure 6}

Mean sediment erosion rates for each season (means averaged over land use and stream order). Season 1-December through March; Season 2-April through July; and Season 3-August through November.

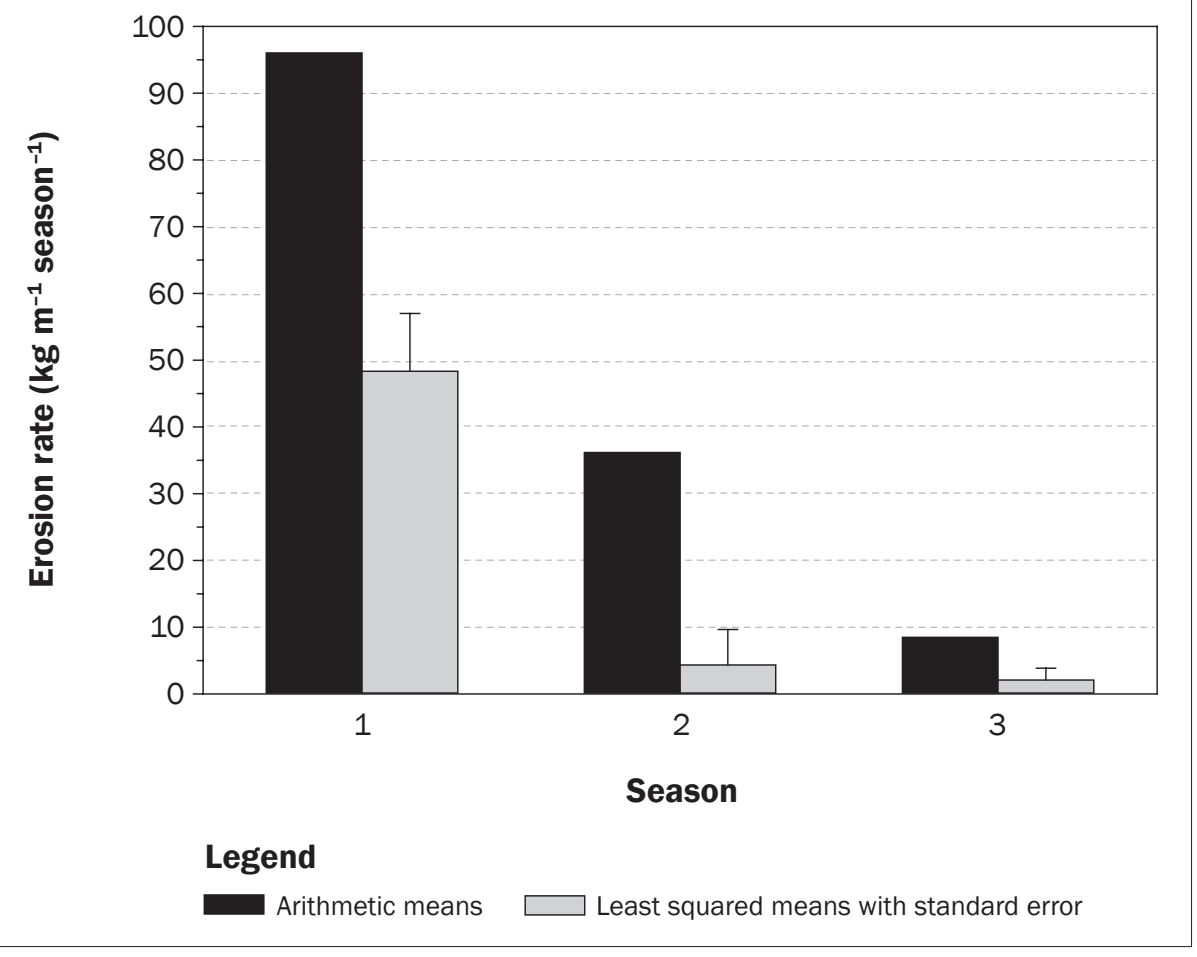

rates, which masked the land use and stream order effects within a given season. Others have noted that the highly variable nature of streambank erosion data makes it very difficult to discern treatment differences (Belsky et al. 1999). Furthermore, not only were the erosion measurements highly variable among the treatments, key sources of variation, such as upstream land use and drainage area, were not controlled. To sufficiently analyze the threeway interaction, pair-wise comparisons were made by varying one of the effects while the other two effects were fixed (figure 7). When considering the significant interaction between season, stream order, and land use, some pairwise comparisons were significant, but they were not useful for making generalizations.

Land use was not a significant main effect in the three-way ANOVA, and only one pair-wise comparison was significant. In Season 2, 2nd order crop sites had significantly lower sediment rates (LS mean $=-32$ $\mathrm{kg} \mathrm{m}$ season $^{-1}\left[-22 \mathrm{lb} \mathrm{ft}^{-1}\right.$ season $\left.\left.^{-1}\right]\right)$ than 2nd order forest sites (LS mean $=107 \mathrm{~kg} \mathrm{~m}^{-1}$ season $^{-1}\left[72 \mathrm{lb} \mathrm{ft}^{-1}\right.$ season $\left.\left.^{-1}\right]\right)(p<0.0001$ in Model 1, $p=0.0007$ in Model 2) (figure 7b). This was likely the result of site-specific differences rather than any true land use effect. The variable response of the land use treat- ments to stream order and season (figure 7) indicated that either upstream factors or vegetation immediately adjacent to the banks had more impact on streambank erosion rates than adjacent land use. Currently, the drainage area, drainage network, and land use data upstream of all sites are being compiled to assess variations in these factors and how they may affect the observed erosion rates. Vegetation surveys are being conducted to assess the importance of adjacent vegetation to streambank erosion (Peacher 2011).

While this study showed nonsignificant differences between land use treatments, past studies have found significant differences between land uses. Zaimes et al. (2004) found that 2 nd order streams flanked by row-crop and pasture fields had higher erosion rates than those with recently constructed riparian forest buffers. Other researchers found that the presence of cattle negatively affected the ability of plant roots to hold soil and that trampling on and along banks causes destabilization (Belsky et al. 1999). Pasture sites in this study were observed to be more prone to slumping because of cattle access to the streams, but this did not result in significantly increased erosion compared to other land uses. 
Table 3

Summary of sediment loss rate least squared means* and analysis of variance (ANOVA) statisticst. Season 1 is December through March, Season 2 is April through July, and Season 3 is August through November.

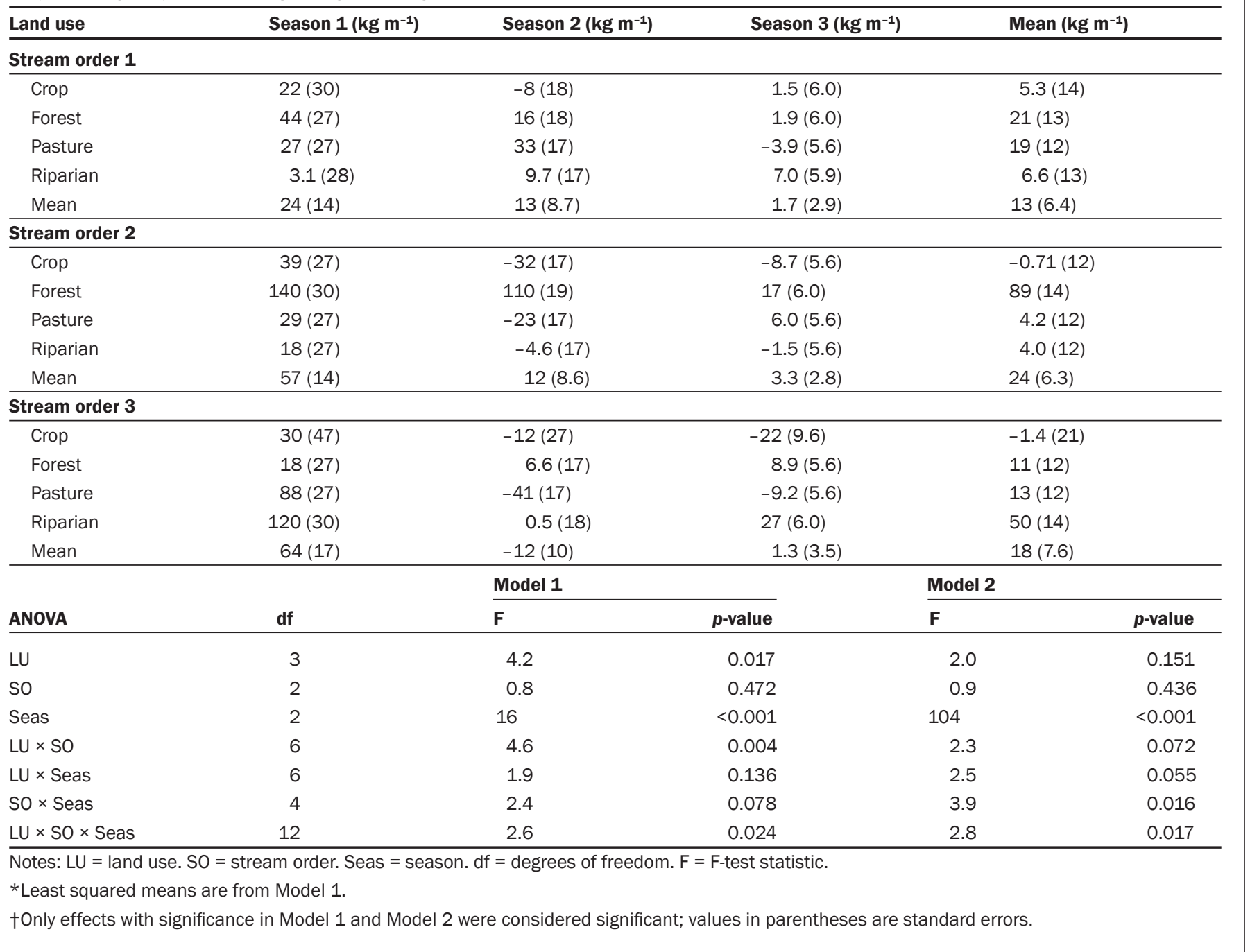

Stream order was not a significant main effect in the three-way ANOVA, and there were no significant pair-wise comparisons between stream orders when land use and season were fixed and stream order was varied. The National Hydrography Data Set (Dewald and Roth 1998) uses the Strahler stream order system, which assigns stream order based on tributary hierarchy (Strahler 1957). While stream order is roughly correlated to the size of the channel, the assignment of a stream order number is mostly independent of other factors controlling streambank processes, such as channel shape and slope, watershed area, sinuosity, and topography. Other than their relative place within the hierarchy of the drainage network, streams of the same order in this study often shared little in common regarding the upstream characteristics that may control streambank erosion. In addition, 2nd order forest sites had much greater erosion rates than 1st or 3rd order forest sites (figure 7), indicating that site-specific factors were likely controlling the erosion rates of these sites rather than adjacent land use or stream order. Given the overall similarity in erosion rates as a function of stream order (figure 5), it appears that stream order designations have little relationship to streambank erosion processes, and this method of categorizing streams was not a useful basis for predicting streambank erosion rates in claypan watersheds. In this region, the high clay content soils could result in critical bank heights that are quite tall regardless of the stream order designation. In an area with less cohesive bank materials, critical bank height is shorter and perhaps more correlated with stream order designation.
Seasonal effects were found to be highly significant $(p<0.001)$, and mean erosion rates were in the order Season $1>$ Season $2>$ Season 3 (figure 6). While this result may seem straightforward based on the arithmetic means, the significant three-way interaction among main effects indicates that a more complex interpretation of the effect of season on erosion rates must be considered. While some confusion exists in the literature regarding the interpretation of significant interaction effects in factorial designs (Jaccard 1998), the interpretation used here was that if a significant interaction between two or more main effects occurred, then the main effect cannot be interpreted unambiguously (Maxwell and Delany 1990). Therefore, to understand the complexity of the season by land use by stream order interaction, the pair-wise comparisons must be considered 


\section{Figure 7}

Pair-wise comparisons of least squared means within land use treatments by (a) stream order 1 , (b) stream order 2, and (c) stream order 3. Season 1-December through March; Season 2-April through July; and Season 3-August through November.

(a)

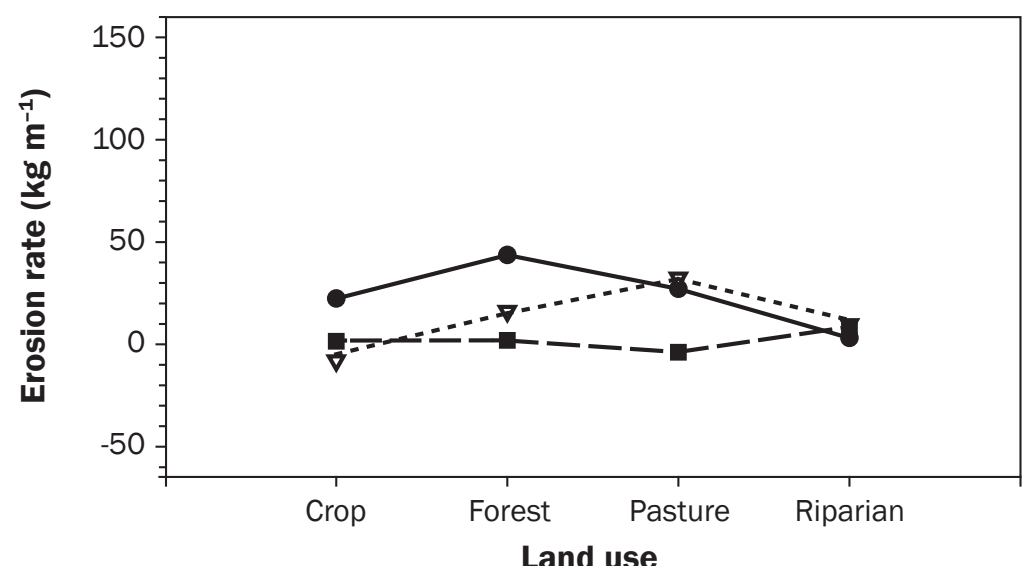

(b)

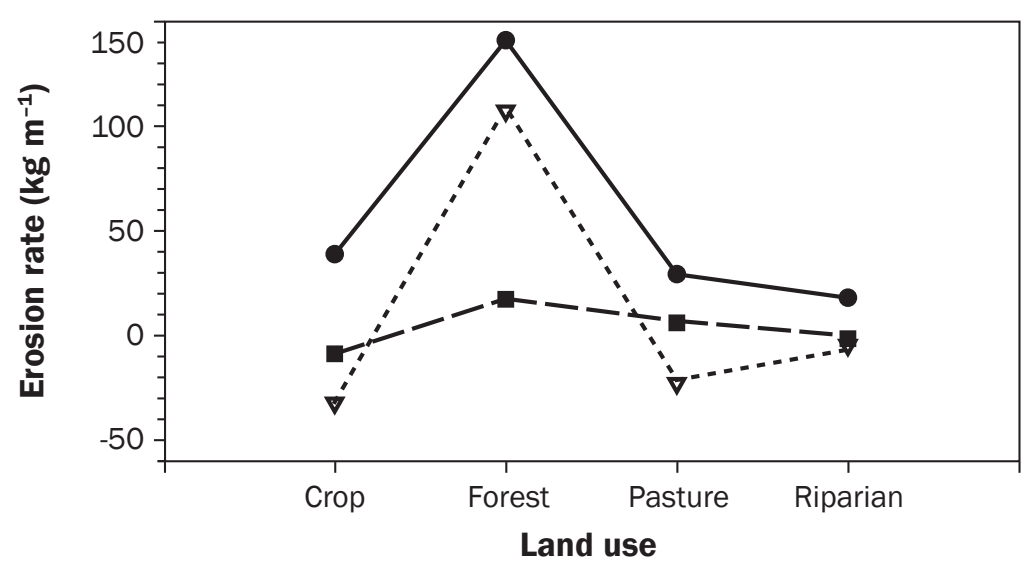

(c)

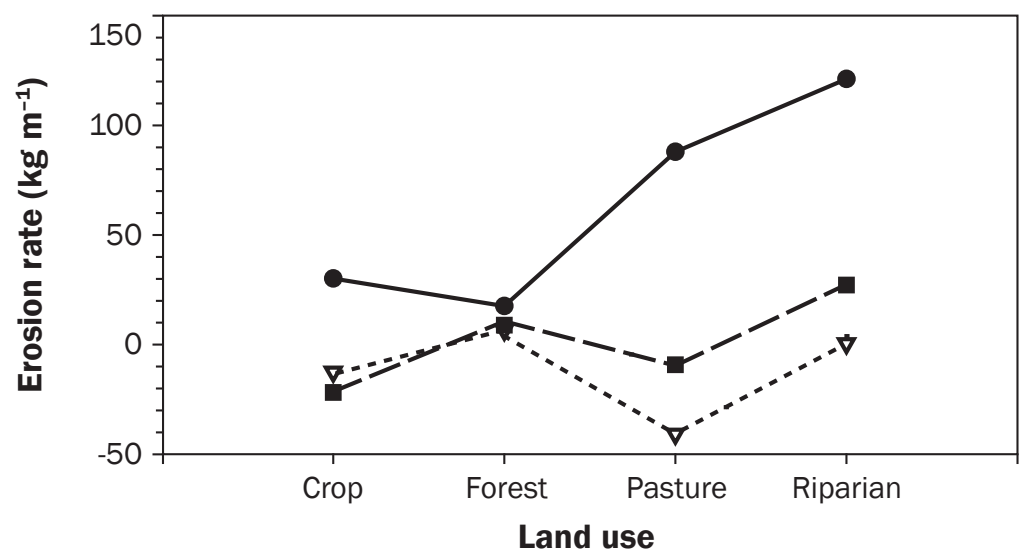

Legend

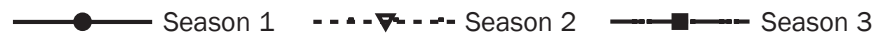

(figure 7). For all significant pair-wise season comparisons, of which there were six, Season 1 was greater than either Season 2 or 3 (figure 7). This supports the general trend seen in figure 6 where the average erosion rate during Season 1 was numerically larger than Season 2 or 3 . However, this trend was only statistically significant for some combinations of land use and stream order. Pair-wise comparisons indicated that 2 nd order forest sites had significantly greater erosion rates in Season 1 than in Season 3 ( $p=0.0003$ in Model 1, $p<0.0001$ in Model 2) (figure 7b). The 3rd order pasture sites had greater erosion rates in Season 1 than Season $2(p=$ 0.0001 in Model $1, \mathrm{p}<0.0001$ in Model 2) and Season $3(p=0.0013$ in Model $1, p$ $<0.0001$ in Model 2) (figure 7c). The same trend was true for 3rd order riparian forest sites, where Season 1 was significantly greater than Season $2(p=0.0004$ in Model $1, p<0.0001$ in Model 2) and Season $3(p=$ 0.0037 in Model $1, p<0.0001$ in Model 2) (figure 7c). Note that while Season 1 often had greater erosion rates than Seasons 2 and 3 , it was not always significantly greater, nor was it numerically greater for every combination. Generally speaking, however, the pair-wise comparisons did support the trend observed in figure 6 .

There is a large literature base supporting the conclusion that season is a significant effect, and the findings of this study are consistent with past studies. Wolman (1959) observed the greatest erosion rates during the winter months (December through March) and lower erosion rates in the summer. Zaimes et al. (2006) reported similar results, with the largest magnitude erosion occurring in the spring and early summer and little erosion occurring in the fall. Lawler et al. (1999) likewise observed higher rates of erosion in the winter months, commenting that most erosion occurs between December and March.

Wolman (1959) attributed some winter erosion to freeze/thaw mechanisms but concluded that winter erosion was largely a result of high flow events occurring when the bank soils were already saturated. Flow events in summer months occurred when bank soils were generally drier than in the winter months and therefore did not produce erosion rates that were as large as those seen in the winter. Even when summer flow events greatly exceeded those occurring in the winter (figure 8), the resulting erosion 
Figure 8

Average daily discharge and precipitation for Crooked Creek from December 2007 through December 2009.

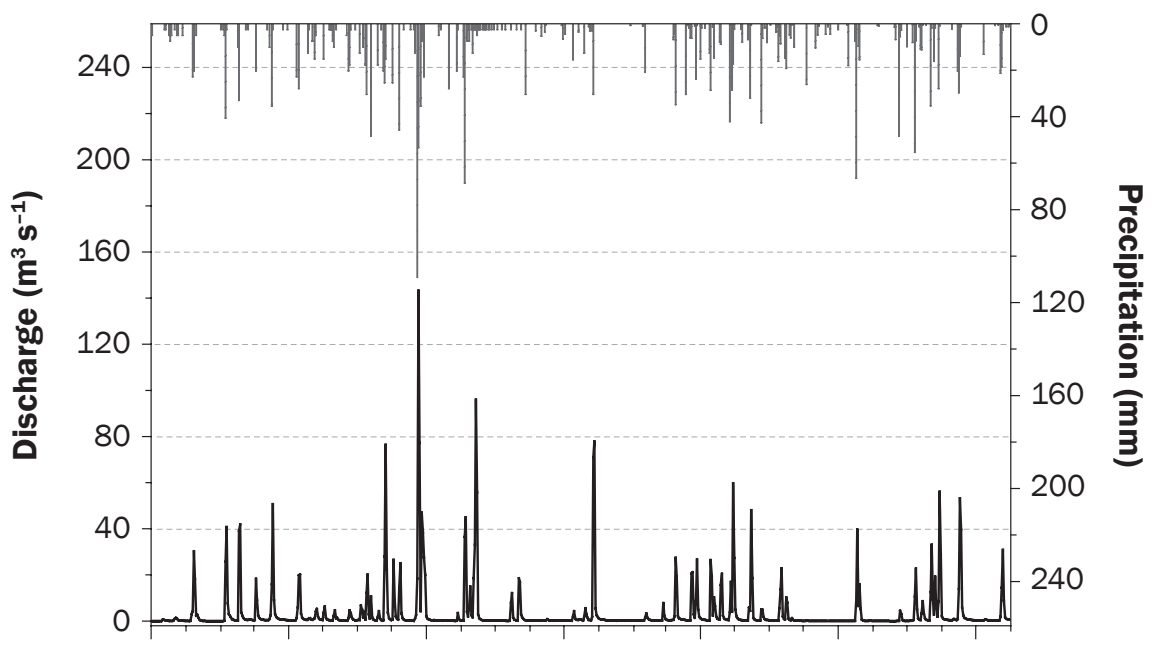

Dec. 2007 Apr. 2008 Aug. 2008 Dec. 2008 Apr. 2009 Aug. 2009 Dec. 2009

Date

\section{Legend}

— Discharge - Precipitation

Table 4

Summary of soil nutrient concentration least squared means and ANOVA statistics.

\begin{tabular}{|c|c|c|c|c|}
\hline Land use & Carbon $\left(\mathrm{g} \mathrm{kg}^{-1}\right)$ & & Nitrogen $\left(\mathrm{g} \mathrm{kg}^{-1}\right)$ & \\
\hline Crop & 15 (2.9)a & & $1.3(0.23) \mathrm{c}$ & \\
\hline Forest & $10(2.6) \mathrm{b}$ & & $0.84(0.30) d$ & \\
\hline Pasture & $13(2.4) \mathrm{a}$ & & $1.1(0.28) c$ & \\
\hline Riparian & $13(2.5) a$ & & $1.1(0.26) \mathrm{cd}$ & \\
\hline ANOVA & Carbon F & Carbon p-value & Nitrogen F & Nitrogen $p$-value \\
\hline Land use & 4.3 & 0.013 & 3.7 & 0.024 \\
\hline Stream order & 0.32 & 0.732 & 0.18 & 0.837 \\
\hline
\end{tabular}

Notes: Values in parentheses are standard errors. Means followed by the same letter were not significantly different at $p=0.05$.

was less (Wolman 1959). Furthermore, a study by Hooke (1979) revealed that while soil moisture was the most important factor controlling streambank erosion, significant erosion only occurred in association with peak discharge. Zaimes et al. (2006) identified precipitation pattern as a major factor contributing to the seasonal effect on bank erosion, finding that most erosion occurred following many medium-sized precipitation events or two large precipitation events that occurred close together. This pattern fits that described by Wolman (1959), where banks become saturated during the first precipitation event and then were eroded during subsequent events. Lawler et al. (1999) described winter conditions of high frequency and large magnitude events, freeze/thaw cycles, high antecedent moisture conditions, and lack of vegetation as the "optimum combination" for producing large amounts of bank erosion, and the results of this study support that conclusion.

Considering the erosion data in light of the discharge data for Crooked Creek (US Geological Survey 2009) (figure 8) reveals an example where many moderate-sized events in Season 1 of 2008 and very infrequent low magnitude events during Season 1 of 2009 produced considerably more erosion than that caused by the frequent medium to high magnitude events that occurred in Seasons 2 and 3 of 2008 and 2009. The high frequency of summer events suggested that wet bank conditions might have persisted through Seasons 2 and 3 of 2008 and 2009, and the disparity between seasonal erosion rates was therefore not entirely explained by saturated bank conditions. Zaimes et al. (2006) attributed additional seasonal differences in erosion rates to seasonal variation in vegetative cover density. Lack of vegetation in the winter leaves banks completely exposed and vulnerable to scour, while lack of evapotranspiration prevents banks from drying. This combination maintains saturated conditions and weakens the cohesion of bank material, resulting in a high degree of vulnerability to erosion during the winter months (Lawler et al. 1999). In contrast, dense vegetative cover in the summer months protects banks from scour, and evapotranspiration dries bank soil, mitigating the erosive effects of even exceptionally wet years with multiple sequential flow events in Seasons 2 and 3 (figure 8).

Nutrient Concentrations and Loss Rates. The results of the carbon and nitrogen concentration data analysis showed that land use had a significant effect (table 4). Stream order and the interaction term (land use by stream order) were not significant for either the $\mathrm{C}$ or $\mathrm{N}$ concentration data $(p=0.48$ for $\mathrm{C}$ and $p=0.40$ for $\mathrm{N}$ ). Pair-wise comparisons showed that forested sites had significantly lower $\mathrm{C}$ and $\mathrm{N}$ concentrations than the other land uses (table 4). The high flooding frequency, which is prevalent throughout these watersheds and is common to all the land uses, controls the deposition of alluvial materials and was likely the reason for the overall similarity in $\mathrm{C}$ and $\mathrm{N}$ concentrations between land uses. The factors working to modify alluvial deposits, and therefore, the factors that account for differences between land uses, include local vegetation, nutrient cycling efficiency, and a combination of adjacent land use and proximity to eroding fields. Because the forest treatment was defined as

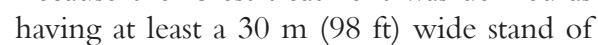
trees, these sites by design lack proximity to surrounding crop and pasture land. Surface runoff would have a longer and more circuitous route to the streambanks of the forested sites than the other treatments. As such, the nutrient inputs from adjacent crop and pas- 
Table 5

Summary of carbon loss rate least squared means* and ANOVA statisticst. Season 1 is December through March, Season 2 is April through July, and Season 3 is August through November.

\begin{tabular}{|c|c|c|c|c|c|}
\hline Land use & Season $1\left(\mathrm{~g} \mathrm{~m}^{-1}\right)$ & Season $2\left(\mathrm{~g} \mathrm{~m}^{-1}\right)$ & Season $3\left(\mathrm{~g} \mathrm{~m}^{-1}\right)$ & \multicolumn{2}{|c|}{ Mean $\left(\mathrm{g} \mathrm{m}^{-1}\right)$} \\
\hline Crop & $450(350)$ & $-110(190)$ & $31(97)$ & \multicolumn{2}{|c|}{$120(170)$} \\
\hline Pasture & $580(340)$ & $630(170)$ & $-1.5(92)$ & \multicolumn{2}{|c|}{$400(160)$} \\
\hline Riparian & $400(340)$ & $440(180)$ & $170(95)$ & \multicolumn{2}{|c|}{340 (170) } \\
\hline Mean & $450(170)$ & $290(90)$ & $60(48)$ & \multicolumn{2}{|c|}{$270(83)$} \\
\hline Crop & $790(340)$ & $-310(170)$ & $-110(92)$ & \multicolumn{2}{|c|}{$120(160)$} \\
\hline Forest & $1,200(360)$ & $820(190)$ & $140(97)$ & \multicolumn{2}{|c|}{$710(170)$} \\
\hline Pasture & $600(340)$ & $-120(170)$ & $120(92)$ & \multicolumn{2}{|c|}{$200(160)$} \\
\hline Riparian & $320(340)$ & $-9.2(170)$ & $-8.6(92)$ & \multicolumn{2}{|c|}{$100(160)$} \\
\hline Mean & $720(170)$ & $94(89)$ & $35(47)$ & \multicolumn{2}{|c|}{$280(82)$} \\
\hline \multicolumn{6}{|l|}{ Stream order 3} \\
\hline Riparian & $1,600(350)$ & 35 (190) & $430(97)$ & \multicolumn{2}{|c|}{$690(170)$} \\
\hline \multirow[t]{2}{*}{ Mean } & $980(210)$ & 35 (110) & $75(57)$ & \multicolumn{2}{|c|}{$360(100)$} \\
\hline & & Model 1 & & \multicolumn{2}{|c|}{ Model 2} \\
\hline ANOVA & df & $\mathbf{F}$ & $p$-value & $\mathbf{F}$ & $p$-value \\
\hline LU & 3 & 0.58 & 0.632 & 1.1 & 0.379 \\
\hline so & 2 & 0.3 & 0.742 & 5 & 0.016 \\
\hline Seas & 6 & 24 & $<0.001$ & 170 & $<0.001$ \\
\hline $\mathrm{LU} \times \mathrm{SO}$ & 2 & 2.3 & 0.070 & 7.3 & $<0.001$ \\
\hline LU $\times$ Seas & 6 & 1.2 & 0.330 & 3 & 0.028 \\
\hline SO $\times$ Seas & 4 & 2.9 & 0.044 & 13 & $<0.001$ \\
\hline
\end{tabular}

Notes: $\mathrm{LU}=$ land use. $\mathrm{SO}=$ stream order. Seas $=$ season. $\mathrm{df}=$ degrees of freedom. $\mathrm{F}=\mathrm{F}$-test statistic.

* Least squared means from Model 1.

†Only effects with significance in Model 1 and Model 2 were considered significant; values in parentheses are standard errors.

ture fields would impact the other land use treatments more than the forested treatment sites. This lack of proximity may account in part for the lower $\mathrm{N}$ concentration of the forest bank materials. Walker et al. (2009) found that restored riparian zones, which were previously degraded by cattle grazing, had lower $\mathrm{N}$ concentrations than grazed sites and were highly efficient at reducing inorganic $\mathrm{N}$ contributions to adjacent stream water. It has further been suggested that even subtle disturbances in riparian areas can influence nutrient cycling in a watershed (Bolstad and Swank 1997; Walker et al. 2009), and the conversion of forested land to row-crop field and pasture in these watersheds over the last 100 years certainly represents major disturbance to the riparian areas of these watersheds.

The ANOVA for the $\mathrm{C}$ and $\mathrm{N}$ loss rates showed that the season effect, stream order by season, and the three-way interaction were significant (tables 5 and 6). The significant pair-wise comparisons showed similar results to that of the sediment loss rates. When differences existed, Season 1 was greater than Season 2 or 3 (data not shown). Of the eight significant pair-wise comparisons for season, six indicated that Season 1 was greater than either Season 2 or 3 . The other two significant pair-wise comparisons showed that 2 nd order forest and 1st order pasture sites had greater nutrient loss rates in Season 2 than Season 3.

Applying Results to Watershed Scale. When considering the contribution of streambank material as a percentage of the total in-stream sediment, a simplifying assumption was made that overland erosion and streambank erosion were the only two sources of sediment in the watersheds. Gullies act as a conduit for delivering overland sediment to streams, so their contribution to in-stream sediment was accounted for in the overland erosion estimate. However, watersheds with actively incising and down-cutting streams should include bed material as a source of sediment. The streams in the Crooked and Otter Creek watersheds are in the degradation and widening phase, or Stage III and Stage IV in channel evolution (Schumm et al. 1984). Following the clearing of the land for cultivation, the stream system would have experienced a large in-flux of overland sediment. This postsettlement alluvium, along with the constant sediment supply from overland and bank sources, protects the bed from degradation as the stream uses all its power to deal with these sources of sediment. Very rarely is the substratum even exposed to be vulnerable to erosion. Additionally, there is so 
Table 6

Summary of nitrogen loss rate least squared means* and ANOVA statisticst. Season 1 is December through March, Season 2 is April through July, and Season 3 is August through November.

\begin{tabular}{|c|c|c|c|c|c|}
\hline Land use & Season $1\left(\mathrm{~g} \mathrm{~m}^{-1}\right)$ & Season $2\left(\mathrm{~g} \mathrm{~m}^{-1}\right)$ & Season $3\left(\mathrm{~g} \mathrm{~m}^{-1}\right)$ & Mean $\left(\mathrm{g} \mathrm{m}^{-1}\right)$ & \\
\hline \multicolumn{6}{|l|}{ Stream order 1} \\
\hline Crop & $41(29)$ & $-10(14)$ & $2.1(8.4)$ & $11(14)$ & \\
\hline Forest & $29(28)$ & $15(14)$ & $3.5(8.4)$ & $16(14)$ & \\
\hline Pasture & $51(28)$ & $54(13)$ & $0.66(8.0)$ & $35(13)$ & \\
\hline Riparian & $40(29)$ & $41(14)$ & $15(8.2)$ & $32(14)$ & \\
\hline Mean & $40(14)$ & $25(7)$ & $5.4(4.1)$ & $24(6.9)$ & \\
\hline \multicolumn{6}{|l|}{ Stream order 2} \\
\hline Crop & $73(28)$ & $-21(14)$ & $-8.3(8.0)$ & $15(13)$ & \\
\hline Forest & $92(30)$ & 55 (15) & $10(8.4)$ & $53(14)$ & \\
\hline Pasture & $56(28)$ & $-6.7(14)$ & $10(8.0)$ & $20(13)$ & \\
\hline Riparian & $28(28)$ & $-0.10(14)$ & $-0.58(8.0)$ & $9.2(13)$ & \\
\hline Mean & $62(14)$ & $6.9(6.9)$ & $3.0(4.1)$ & $24(6.8)$ & \\
\hline \multicolumn{6}{|l|}{ Stream order 3} \\
\hline Crop & $81(49)$ & $33(23)$ & $-13(14)$ & $34(23)$ & \\
\hline Forest & $23(28)$ & $11(14)$ & $10(8.0)$ & $15(13)$ & \\
\hline Pasture & $110(28)$ & $-21(14)$ & $-6.1(8.0)$ & $27(13)$ & \\
\hline Riparian & $140(29)$ & $3.3(14)$ & $38(8.4)$ & $59(14)$ & \\
\hline \multirow[t]{2}{*}{ Mean } & $88(17)$ & $6.7(8.4)$ & $7.0(5.0)$ & $34(8.3)$ & \\
\hline & & \multicolumn{2}{|l|}{ Model 1} & \multicolumn{2}{|l|}{ Model 2} \\
\hline ANOVA & df & $\mathbf{F}$ & $p$-value & $\mathbf{F}$ & $p$-value \\
\hline LU & 3 & 0.38 & 0.769 & 1.0 & 0.400 \\
\hline so & 2 & 0.54 & 0.590 & 1.6 & 0.225 \\
\hline Seas & 6 & 27 & $<0.001$ & 71.0 & $<0.001$ \\
\hline $\mathrm{LU} \times \mathrm{SO}$ & 2 & 2.0 & 0.106 & 3.1 & 0.023 \\
\hline LU $\times$ Seas & 6 & 1.2 & 0.351 & 1.8 & 0.148 \\
\hline SO $\times$ Seas & 4 & 3.2 & 0.034 & 5.8 & 0.003 \\
\hline LU $\times$ SO $\times$ Seas & 12 & 2.8 & 0.018 & 3.9 & 0.003 \\
\hline
\end{tabular}

Notes: $\mathrm{LU}=$ land use. $\mathrm{SO}=$ stream order. Seas $=$ season. $\mathrm{df}=$ degrees of freedom. $\mathrm{F}=$ F-test statistic.

* Least squared means from Model 1.

†Only effects with significance in Model 1 and Model 2 were considered significant; values in parentheses are standard errors.

\section{Table 7}

Streambank sediment and nutrient transport in the Crooked and Otter Creek study area.

\begin{tabular}{|c|c|c|c|c|}
\hline Stream order & $\begin{array}{l}\text { Bank length } \\
\text { (km) }\end{array}$ & $\begin{array}{l}\text { Erosion rate } \\
\left(\mathrm{kg} \mathrm{m}^{-1} \mathrm{y}^{-1}\right)\end{array}$ & $\begin{array}{l}\text { Carbon } \\
\text { loss rate } \\
\left(\mathrm{g} \mathrm{m}^{-1} \mathbf{y}^{-1}\right)\end{array}$ & $\begin{array}{l}\text { Nitrogen } \\
\text { loss rate } \\
\left(\mathrm{g} \mathrm{m}^{-1} \mathrm{y}^{-1}\right)\end{array}$ \\
\hline $1 s t$ & 704 & 132 & 1,600 & 131 \\
\hline 2nd & 323 & 132 & 1,440 & 115 \\
\hline $3 r d+$ & 338 & 161 & 1,650 & 156 \\
\hline Watershed $\left(\mathrm{Mg}^{-1}\right)$ & & 190,000 & 2,150 & 182 \\
\hline Range $\left(\mathrm{Mg}^{-1}\right)^{*}$ & & \pm 976 & \pm 42.5 & \pm 5.87 \\
\hline
\end{tabular}

* Ranges were calculated based on data from 2008 and 2009.

little relief in these watersheds and so much sediment from bank and overland sources that there is little energy available for degrading the bed. Furthermore, Mark Twain Lake, which is located at the outlet of the two streams, has effectively raised the base level by 15 to $30 \mathrm{~m}$ (49 to $98 \mathrm{ft}$ ). Thus, these streams cannot incise below the level of the lake. Given this setting, the contribution of streambed degradation to in-stream sediment was considered negligible.
The total amount of sediments from streambanks in the study area was estimated to be $190,000 \pm 976 \mathrm{Mg} \mathrm{y}^{-1}(210,000 \pm$

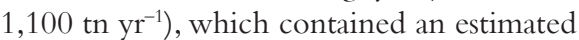
$2,150 \pm 42.3 \mathrm{Mg} \mathrm{C} \mathrm{y}^{-1}(2,370 \pm 46.6$ tn C $\left.\mathrm{yr}^{-1}\right)$ and $182 \pm 5.87 \mathrm{Mg} \mathrm{N} \mathrm{y}^{-1}(200 \pm 6.47$ th $\mathrm{N} \mathrm{yr}^{-1}$ ) (table 7). Total overland erosion was estimated at $474,000 \mathrm{Mg} \mathrm{y}^{-1}(521,400$ tn $\mathrm{yr}^{-1}$ ) (table 2). Sediment delivery ratio estimates ranged from $2.5 \%$ to $11 \%$, with an average of $6.0 \% \pm 4.1 \%$ (standard deviation) for a $280 \mathrm{~km}^{2}\left(108 \mathrm{mi}^{2}\right)$ watershed. Using the average SDR combined with the overland erosion rates for the study area results in an estimate of $28,000 \pm 19,000 \mathrm{Mg} \mathrm{y}^{-1}$ $\left(30,900 \pm 20,900 \mathrm{tn}^{-1}\right)$ of overland sediment reaching the stream channels of Crooked and Otter Creek. Based on these two estimates, streambanks accounted for $79 \%$ to $96 \%$ (mean of $88 \%$ ) of the total in- 


\section{Figure 9}

Contribution of streambank sediment to the total in-stream sediment of Crooked and Otter Creek.

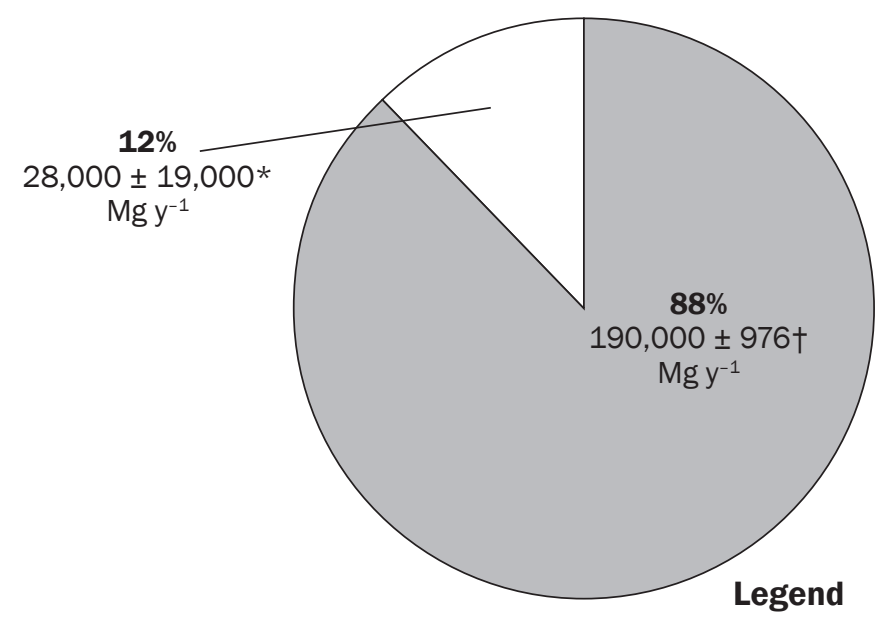

* Indicates the standard deviation based on the sediment delivery ratio.

†Indicates the range.

\section{Figure 10}

Contribution of streambank sediment to the total nitrogen exported from study area. Total nitrogen exported was estimated to be $800 \pm 29^{\star} \mathrm{Mg} \mathrm{y}^{-1}$.

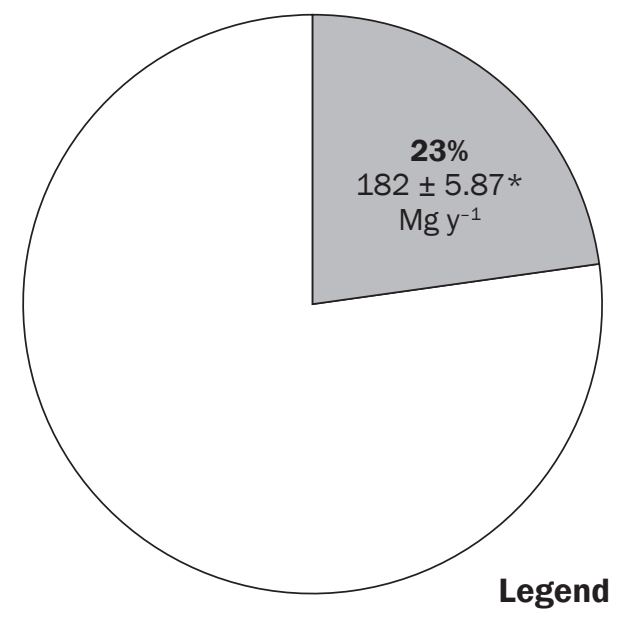

*Indicates the range.

$\square$ Bank nitrogen

stream sediment in the study area (figure 9), indicating that streambank erosion was the dominant source of in-stream sediment for these two watersheds. These results are at the high end of what is reported in the literature. Wilson et al. (2008), using stable isotopes as indicators of overland and bank sediment sources, found that streambanks accounted for $54 \%$ to $80 \%$ of the in-stream sediment load at five sites in the southern and midwestern United States. In light of the fact that 2008 and 2009 were both exceptionally wet years (2.6 and 1.7 times greater than the 20-year mean daily discharge, respectively) (US Geological Survey 2009), it is not unreasonable that our scaled-up results would fall in the upper range of previously reported values. Additionally, given the extensive land disturbance in these watersheds, it is likely that these watersheds are not yet in equilibrium and, therefore, have higher erosion rates than those in other watersheds.

Based on the water quality monitoring data, the total $\mathrm{N}$ transported from the study area was estimated to be $800 \pm 29 \mathrm{Mg} \mathrm{y}^{-1}$

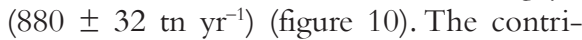
bution of streambanks was $182 \pm 5.87 \mathrm{Mg}$ $\mathrm{y}^{-1}\left(200 \pm 6.47\right.$ tn $\left.\mathrm{N} \mathrm{yr}^{-1}\right)$ (table 7 ), or $23 \%$ of the annual total $\mathrm{N}$ exported from both watersheds (figure 10). Thus, streambanks were also an important source of $\mathrm{N}$ to the streams. No previous reports of the contribution of streambanks to the total $\mathrm{N}$ load of a watershed could be found for comparison. Although C transport data were not available for these watersheds, it is probable that streambanks also contributed considerably to the $\mathrm{C}$ load of these watersheds given the importance of streambank erosion to instream sediment and $\mathrm{N}$ loads.

Management Implications. Comparing the contribution of bank and overland sediment underscores the need for targeting management efforts to mitigate streambank erosion. While overland erosion is by far the major source of gross watershed erosion, this work has demonstrated the importance of streambanks as the major source of in-stream sediment and as a key source of nutrients in claypan watersheds. Currently, conservation practices in these watersheds emphasize BMPs that address overland erosion and little effort has been focused on controlling streambank erosion. These data suggest that reducing streambank erosion would significantly improve the water quality, in terms of sediment and nutrient contamination, of these streams.

Unfortunately, management strategies that address the seasonal component of streambank erosion processes are limited. There are, however, many practices available for mitigating streambank erosion year round, including traditional engineering approaches (Bentrup and Hoag 1998; Schultz et al. 2004), bioengineered systems (Bentrup and Hoag 1998), and establishment of riparian forest buffers and grass buffer strips (Gregory et al. 1991; Schulz et al. 2004). There is also extensive evidence that exclusion of cattle from riparian zones, either as part of a rotational grazing system or by fencing them from streambanks, reduces erosion (Platts 1981; Kauffman and Krueger 1984; Bentrup and Hoag 1998; Belsky et al. 1999; Sovell 
et al. 2000; Clary and Kinney 2002; Walker et al. 2009). Given the seasonal nature of streambank processes observed in this study, exclusion of cattle from streambanks during the winter months may be especially beneficial. Currently, establishment of streambank stabilization measures are voluntary, and therefore, despite government programs and practices available to landowners for streambank erosion mitigation, the riparian zones and streambanks in the study area, and across the Midwest, are largely unmanaged (Lyons et al. 2000).

\section{Summary and Conclusions}

Of the three main factors assessed in this study, only season showed a significant impact on streambank erosion rates in Crooked and Otter Creek watersheds, while land use and stream order were not significant factors. The lack of a land use effect was attributed to either variation in up-stream factors or variation in vegetation immediately adjacent to the streambanks. Both of these possibilities are currently being investigated. Stream order was not a significant factor influencing streambank erosion rates because in these claypan watersheds stream order designation is largely independent of the factors controlling erosion processes. Season was found to be a highly significant factor affecting streambank erosion, with most erosion occurring in the winter months. However, a simple interpretation of the seasonal effect was not warranted as a significant three-way interaction between land use, stream order, and season also existed. This three-way interaction, as well as the lack of adjacent land use effects, highlights the complex and highly variable nature of streambank erosion processes. Nutrient concentrations of bank soils were significantly lower in forest sites, which may be due to the lack of proximity to adjacent crop land as well as to accelerated nutrient cycling. The nutrient loss rates had significant effects and interaction terms that reflected the sediment loss rates. At the watershed scale, streambank erosion accounted for an average of $88 \%$ of the in-stream sediment and $23 \%$ of the total $\mathrm{N}$ load on an annual basis. These results demonstrated that streambanks were the primary source of sediment in these streams and also a considerable source of the total $\mathrm{N}$ transported from these watersheds. Moreover, adoption of management practices that decrease streambank erosion would result in significant water quality improvement in streams of the Central Claypan Areas.

Given the lack of an adjacent land use effect, further research is needed to determine the specific factors controlling streambank erosion (i.e., upstream characteristics and/or on- and above-bank vegetation) to maximize the effectiveness of BMPs implemented within the riparian zone. Controlling instream sedimentation in these watersheds will not only require continued efforts to reduce overland erosion, but additional efforts will also be needed to minimize streambank erosion by targeting BMPs to riparian areas.

\section{Acknowledgments}

The authors wish to thank all the USDA Agricultural Research Service and Iowa State University staff and students that made this project possible. Special thanks to Bettina Coggeshall and Jen (Nelson) Frohnauer, soil scientists with the USDA Agricultural Research Service; Leigh Ann Long, research associate, Iowa State University; and Amber Spohn, physical science technician, USDA Agricultural Research Service, for their dedicated efforts throughout this study. A very special thanks to the many landowners that provided access to their land for this study.

\section{Disclaimer}

Mention of specific companies, products, or trade names is made only to provide information to the reader and does not constitute endorsement by the USDA Agricultural Research Service.

\section{References}

Belsky, A.J., A. Matzke, and S. Uselman. 1999. Survey of livestock influences on stream and riparian ecosystems in the western United States. Journal of Soil and Water Conservation 54(1):419-431.

Bentrup, G., and J.C. Hoag. 1998. The Practical Streambank Bioengineering Guide-User's Guide for Natural Streambank Stabilization Techniques in the Arid and Semiarid Great Basin and Intermountain West. Aberdeen, ID: USDA NRCS, Interagency Riparian/ Wetland Plant Development Project.

Berges, S.A. 2009. Ecosystem services of riparian areas: Stream bank stability and wildlife habitat. Master's thesis. Ames IA: Iowa State University.

Bolstad, P.V., and W.T. Swank. 1997. Cumulative impacts of land use on water quality in a southern Appalachian watershed. Journal of American Water Resources Association 33(3):519-533.

Clary, W.P., and J.W. Kinney. 2002. Streambank and vegetation response to simulated cattle grazing. Wetlands 22(1):139-148.

Couper, P., T. Stott, and I. Maddock. 2002. Insights into river bank erosion processes derived from analysis of negative erosion-pin recordings: Observations from three recent
UK studies. Earth Surface Processes and Landforms 27(1):59-79

Dewald, T.G., and K.S. Roth. 1998. The National Hydrography Dataset - Integrating the USEPA Reach File and USGS DLG. In Conference Proceedings: 1998 ESRI User Conference, San Diego, California, July 27-31, 1998. Redlands, CA: Environmental Systems Research Institute.

DeWolfe, M.N., W.C. Hession, and M.C. Watzin. 2004. Sediment and Phosphorus loads from streambank erosion in Vermont, USA. In Critical Transitions in Water and Environmental Resources Management, eds. G. Sehlke, D.F. Hayes, and D.K. Stevens. Reston, VA: America Society of Civil Engineers.

Duijsings, J.J.H.M. 1986. Seasonal variation in the sediment delivery ratio of a forested drainage basin in Luxembourg. In Drainage Basin Sediment Delivery, ed. R.F. Hadley. International Association of Hydrological Sciences Publication 159, Wallingford: International Association of Hydrological Sciences.

Fox, G.A., G.V. Wilson, A. Simon, E.J. Langendoen, O. Akay, and J.W. Fuchs. 2007. Measuring streambank erosion due to groundwater seepage: Correlation to bank pore water pressure, precipitation, and stream stage. Earth Surface Processes and Landforms 32:1558-1573.

Gardiner, T. 1983. Some factors promoting channel bank erosion, River Lagan, County Down. Journal of Earth Science Royal Dublin Society 5:231-239.

Greenberg,A.E., A.D. Eaton, and L.S. Clesceri. 1992. Part 4500, Inorganic nonmetallic constituents. In Standard Methods for the Examination of Water and Wastewater, 18th Edition. Washington, DC:American Public Health Association.

Gregory, S.V., F. J. Swanson, W.A. McKee, and K.W. Cummins. 1991. An ecosystem perspective of riparian zones. Bioscience 41(8):540-550.

Hooke, J.M. 1979. An analysis of the processes of river bank erosion. Journal of Hydrology 42(1-2):39-62.

Jaccard, J.1998. Interaction effects in factorial analysis of variance. Sage University Papers Series on Quantitative Applications in the Social Sciences, series No. 07-118. Thousand Oaks, CA: SAGE Publications.

Jamison, C.V., D.D. Smith, and J.F. Thornton. 1968. Soil and water research on a claypan soil. USDA-ARS Technical Bulletin 1379. Washington, DC: US Government Printing Office.

Kauffman, J.B., and W.C. Krueger. 1984. Livestock impact on riparian ecosystems and streamside management implications: A review. Journal of Range Management 37:430-437.

Lawler, D.M. 1993. The measurement of river bank erosion and lateral channel change: A review. Earth Surface Processes and Landforms 18(9):777-821.

Lawler, D.M., J.R. Grove, J.S. Couperthwaite, and G.J.L. Leeks. 1999. Downstream change in river bank erosion rates in the Swale-Ouse system, northern England. Hydrological Processes 13(7):977-992. 
Lerch, R.N., and P.E. Blanchard. 2003. Watershed vulnerability to herbicide transport in northern Missouri and southern Iowa streams. Environmental Science and Technology 37(24):5518-5527.

Lerch, R.N., E.J. Sadler, N.R. Kitchen, K.A. Sudduth, R.J Kremer, D.B. Meyers, C. Baffaut, S.H. Anderson, and C.H. Lin. 2008. Overview of the Mark Twain/Salt River Basin Conservation Effects Assessment Project. Journal of Soil and Water Conservation 63(6):345-359, doi:10.2489/jswc.63.6.345.

Lyons, J., S.W. Trimble, and L.K. Paine. 2000. Grasses versus trees: Managing riparian areas to benefit streams of central North America. Journal of American Water Resources Association 36(4):919-930.

Maner, S.B. 1958. Factors influencing sediment delivery rates in the Red Hills physiographic area. Transactions of the American Geophysical Union 39:669-675.

Maxwell, S.E., and H.D. Delany. 1990. Designing experiments and analyzing data: A model comparison perspective. Belmont, CA: Wadsworth Publishing Company.

McGreal, W.S., and T. Gardiner. 1977. Short term measurements of erosion for a marine and a fluvial environment in County Down, Northern Ireland. Area 9(4):285-289.

National Academy of Sciences. 1986. Soil conservation: Assessing the National Resources Inventory. Vol. 1. Washington, DC: National Academy Press.

Nydahl, F. 1978. On the peroxodisulphate oxidation of total nitrogen in waters to nitrate. Water Resources 12:1123-1130

Peacher, R. 2011. Impacts of land use on stream bank erosion in the Northeast Missouri Claypan Region. Master's thesis. Ames, IA: Iowa State University. http:// lib.dr.iastate.edu/etd/10395.

Piercy, C., and T. Wynn. 2008. Predicting root density in streambanks. Journal of American Water Resources Association 44(2):469-508.

Platts, W.S. 1981. Effects of livestock grazing. In Influence of Forest and Rangeland Management on Anadromous Fish Habitat in Western North America, ed. W.R. Meehan. US Forest Service, Pacific Northwest Forest and Range Experiment Station. Washington, DC: US Forest Service.

Roehl, J.W. 1962. Sediment source area delivery ratios and influencing morphological factors. International Association of Hydrological Sciences 59:202-213.

Schultz, R.C., T.M. Isenhart, W.W. Simpkins, and J.P. Colletti. 2004. Riparian forest buffers in agrosystems - Lessons learned from the Bear Creek Watershed, central Iowa, USA. Agroforestry Systems 61(1):35-50.

Schumm, S.A., M.D. Harvey, and C.C.Watson. 1984. Incised channels: Morphology dynamics and control. Littleton, CO:Water Resources Publication.

Shields, F.D., Jr., S.S. Knight, and C.M. Cooper. 1994. Effects of channel incision on base flow stream habitats and fishes. Environmental Management 18(1):43-57.
Simon, A., M. Rinaldi, and G. Hadish. 1996. Channel evolution in the loess area of the Midwestern United States. In Proceedings of the Sixth Federal Interagency Sedimentation Conference, Las Vegas, Nevada, March 10-14, 1996. Reston, VA: Federal Interagency Sedimentation Conference.

Sovell, L.A., B. Vondracek, J.A. Frost, and K.G. Mumford. 2000. Impacts of rotational grazing and riparian buffers on physiochemical and biological characteristics of southern Minnesota, USA, streams. Environmental Management 26(6):629-641.

Strahler, A.N. 1957. Quantitative analysis of watershed geomorphology. Transactions of the American Geophysical Union 8:913-920.

USDA NRCS (USDA Natural Resources Conservation Service). 1998. Erosion and sediment delivery. Des Moines, IA: USDA Natural Resources Conservation Service.

USDA NRCS. 2000a. Missouri national resources inventory soil erosion tables. Columbia, MO: USDA Natural Resources Conservation Service. http://www.mo.nrcs. usda.gov/technical/nri/soilerosiontbl/out/MOSE15. pdfUSDA NRCS.

USDA NRCS. 2000b. Missouri national resources inventory soil erosion tables. Columbia, MO: USDA Natural Resources Conservation Service. http://www.mo.nrcs. usda.gov/technical/nri/soilerosiontbl/out/MOSE28.pdf.

USDA NRCS. 2006. Land resource regions and major land resource areas of the United States, the Caribbean, and the Pacific Basin. Agricultural Handbook 269 Washington DC: US Government Printing Office.

USDA SCS (Soil Conservation Service). 1983. SCS National engineering handbook, section 3: Sedimentation, 2nd ed. Washington DC: USDA Soil Conservation Service.

US Geological Survey. 2009. Crooked Creek near Paris, MO daily discharge data December 2007 to January 2010. Reston, VA: US Geological Survey. http:// waterdata.usgs.gov $/ \mathrm{mo} / \mathrm{nwis} / \mathrm{uv} /$ ?site_no $=05503800$ \&PARAmeter_cd $=00065,63160,00060$

Walker, J.T., J.M. Vose, J. Knoepp, and C.D. Geron. 2009 Recovery of nitrogen pools and processes in degraded riparian zones in the southern Appalachians. Journal of Environmental Quality 38(4):1391-1399.

Willett, C., S.A. Berges, R.N. Lerch, and R.C. Schultz. 2009 Stream bank erosion rates of small Missouri streams. In Agroforestry comes of age: Putting science into practice, eds. M.A. Gold, and M.M. Hall. Columbia, MO: The Center for Agroforestry. http://www. centerforagroforestry.org/pubs/proceedings.pdf.

Willett, C.D. 2010. Streambank erosion and risk assessment of contaminant transport in Missouri watersheds. Master's thesis. Columbia, MO: University of Missouri.

Wilson, C.G., and R.A. Kuhnle. 2006. Determining relative contributions of eroded landscape sediment to the suspended load of Goodwin Creek using ${ }^{7} \mathrm{Be}$ and ${ }^{210} \mathrm{Pbxs}$. USDA-ARS National Sedimentation
Laboratory Research Report. No. 53. Washington, DC: USDA Agricultural Research Service.

Wilson, C.G., R.A. Kuhnle, D.D. Bosch, J.L. Steiner, P.J. Starks, M.D. Tomer, and G.V.Wilson. 2008. Quantifying relative contributions from sediment sources in Conservation Effects Assessment Project watersheds. Journal of Soil and Water Conservation 63(6):523-532, doi: $10.2489 /$ jswc.63.6.523

Wolman, M.G. 1959. Factors influencing erosion of a cohesive river bank. American Journal of Science 257(3):204-216

Zaimes, G.N., R.C. Schultz, and T.M. Isenhart. 2004. Stream bank erosion adjacent to riparian forest buffers, rowcropped fields, and continuously-grazed pastures along Bear Creek in central Iowa. Journal of Soil and Water Conservation 59(1):19-27.

Zaimes, G.N., R.C. Schultz, and T.M. Isenhart. 2006. Riparian land-uses and precipitation influences on streambank erosion in central Iowa. Journal of American Water Resources Association 42(1):83-97.

Zaimes, G.N., R.C. Schultz, and T.M. Isenhart. 2008. Streambank soil and phosphorus losses under different riparian land-uses in Iowa. Journal of American Water Resources Association 44(4):935-947. 